\title{
Formation of Porphyrin Isomers from Porphobilinogen by Various Hemolysates of Red Cells from Bovine and Human Subjects with Erythropoietic (Uro-) Porphyria')
}

\author{
By C. J. Warson, Irene Bosseniatek and Ruth CakdiNal.
}

University Medical Init, Northwestern Hospital and the Department of Medicine, University of Minnessta, Minneapolis, Minnesota, USA

(Pingcegangen am 6. Januar 1960)

Dedicated to Prof. Dr. Joachim Brugsets on the vccasion of bis $601 \mathrm{~h}$ birthday

\begin{abstract}
Hemolysatcs of crythrseytes from brovine and human subjects havine erythroprictic porphyria, and from normal subjects, have been incubated with PEG ${ }^{2}$. Cells obtained by differential centrifugation of essnestic lysis as well as total cells were hemelyyed. The proportion utilized or unaccusunted for after incubation was gencrally inuch greater with the prophyric than the normal hemelysatcs, with the lesser than the greater density fractions, and with the hemolysates of the osmotically more fragile cells. laryer amrounts of PBG in relation to cells, less pretection against ambient temperature and longer incubation werc associated with grcatcr formation of type 1 porphyrins by normal as well as porphyric hemolysatcs. With morre nearly optimal cenditions, only or mainly type 111 was in evidenec in the nosmal while the porphyric hemolysates formed broth 1 and III. Porphyric hemolysatcs regularly formed larger amounts of protoperphyrin 9 (III) than the normal. After repeated blecding of brsvine prorphyrics, the hernolysates formed larger amounts of porphyrin and significantly greates proportions of type 1 isomer than before bleeding. This is interpreted as an crihanced deaminascoisomerase imbalance in young cells. Under the same conditions the normal bxyinc hemr, lysates frormed mainly type 1II. These obecrvations are considered in respect to the question whether the normoblasts are uni- or bimodal in terms of the genetic abnormality, i. c., the deaminasc-jesmerase imbralance. The present cridence is in better accurd with a unimodal distribution.
\end{abstract}

Erythrocytenhämo,lysate gesunder und an Porphyria erythro,jestica crksanketer Menschen und Rinder wurden mit PQGz) inkutiert. Lur Mämolyse wurden die Yellen in totn oder nach Differentialyentrifugation brw. Osmolyse verowandt. Ein im allgemeinen vicl stärkerer PBC-Schwund wurdc, verglichen mit Normal-Hämeslysaten, in Prorphyric-Häms,lysaten gefunden, ebenso in denen ver leichteren im Vergleich mit schwereren und in denen von osmotisch fragileren \%ellen. Wurde im Verhältnis \%u den Zellen mehr PBG \%ugeset”t ider "yeniger gegen die Umgebungstemperatur geschiützt und länger inkubier, so, wurden sorvohl von normalen als auch von Porphyrie-Hämilysaten mehr Typ-1 Porphyrine gebildet. Wurden dagegen annähernd optimale Bedingungen eingehalten, se wurde vom Nistmal-Hämrilysaten nur oder überwiegend Typ III gebildet, während Porphyric-Hämolysate sowishl Typ I als auch Typ III bildeten. In Porphyric-11ärno,lysaten entstanden im allgemeinen grölfere Mengen Protoporphyrin 9 (III) als in Normal-Hämolysaten. Nach viederholten Aderlässen bildeten die Hämolysate porphyriekranker Rinder grölere Mengen Porphyrin und bedeutend grölbere Anteile des Typ-l-1semeren als vorr den Blutverlusten. Dies wird durch ein gestöttes Desaminase-Isomerase-Glejchgewicht hauptsächlich jugendlicher Zellen crklärt. Linter gleichen Bedingungen bildeten normale Rinder-Hämolysate hauptsächlich Typ 111. Diese Beubachtungen werden in Hinblick. auf die Frage diskutiert, ob Normoblasten eine oder zwei genetische Abweichungen in beidug auf das Desaminase-lsemerase-Gleichgevilcht aufroeisen. Die hier vorgctragenen Ergebnisse stimmen besser damit überein, daß lediglich eine cincige entsprechende Störung vorlicgt.

In earlier studies $(1,2,3)$ the delineation of erythropoietic porphyria, both human and bovine, depended in part on the presence of large numbers of intensely fluorescing normoblasts in the bune marrow. Since

1) Aided by grants from the U. S. Public Health Service, and the Margaret $H$. and James E. Kelley Poundation.

2) Definitions and Abbreviations: PBG = porphobilinogen; $\mathrm{ALA}=$ D-aminolevulinic acid; UP = uroporphyrin wben used in a purely chemical or nun-encymatic context, or uroporphyrinogen in relation to encymatic formation or conversions. 1 or $111=$ corresponding isomer types; $C P=$ coproporphyrin, or copropor. phyrinogen, as above. 1 or $I 11=$ corresponding isomer types; UP $\rightarrow$ CP $=-$ decarboxylation of UP to permit detcrmination of isomer ratio; UPI + CPI = sum of UPI and CPI calculated as UP 1; Proto- = protoporphyxin 9 (series III); Meso =- mesoporphyrín 9 (serics III); 1, d. c. = lesser density cells obtainad by fractional centrifugation; g.d.c. = greater density cells obtained by fractional centrifugation; t. $c_{0}=$ total cells C. B. = CornfordBenson method for chromatogsaphic separation of UPI and III (31); $\mathrm{P}=$ porphyric; $\mathrm{N}=$ normal; $\mathrm{Ht}=$ - hematocrir. other normoblasts, morphologically similar but not fluorescing, comprised approximately half of the total, the possibility was considered that two cell types were represented, functionally distinct, one abnormal and fluorescing due to excessive production of type $I$ uroand coproporphyrins (UP and CP), the other normal, and non-fluorescing as a result of the low concentration of free porphyrin (3).

As suggested elsewhere (4) the fundamental abnormality in this disease may be a regulator gene disturbance with overproduction of porphyrins of both series I and III, the type $I$ porphyrins in relatively great excess as contrasted with the normal state. Recent histologic studies by others $(5,6)$, both by light and electron microscopy, have favored the existence of two separate varietics of normoblasts in this disease, "porphyroblasts" (G), vs. normal nucleated red cells but the question remains whether the differences observed are acquired, related 
to injury, or to temporal functional changes in some of the normoblasts, and whether all are unimodal with respect to the genetic abnormality or whether this involves but one cell type of a bimodal distribution. RIMINGTon (7) observed that on incubation with PBG, a normal bovine erythrocyte hemolysate formed only type III UP, whereas an hemolysate from the red cells of a bull calf homozygous for the trait of erythropoietic porphyria, under the same conditions, formed about equal amounts of types I and III. This finding was compatible with the concept of a bimodal but did not exclude a unimodal distribution.

It was shown in earlier studies (8) that in both the human and bovine disease the osmotically more fragile cells are UP rich, while the more resistant cells contained Proto- but relatively little $\mathrm{UP}^{3}$ ) or $\mathrm{CP}^{3}$ ). Reference was made in an earlier paper (4) to the finding that the UP rich cells are lighter and can be concentrated like the reticulocytes, by centrifugation. This method has been used extensively in the experiments to be described.

In a series of unpublished experiments (9) transfusion of whole blood from bovine porphyrics into normal animals was followed by rapid disappearance of the (transfused) erythrocyte UP in the recipient, while the Proto- leveli returned to the pre-transfusion concentration much more slowly (see below). This might also be explained on the basis of bimodal exythrocytes, one from each of the supposed normoblast colonies earlier postulated. In this respect the bimodal concept would embrace the possibilities that the presumably less mature UP rich cells have a short life span or lose their UP to the circulation, without undergoing destruction. It was also conceivable that the normoblasts and erythrocytes are unimodal in respect to the genetic error but that the UP rich cells simply represent "stress" forms, immature and of short life span $(10,11)$. According to this concept, all of the normoblasts participate in the genetic error but porphyrin production and consequent fluorescence of normoblasts is more dynamic and variable than previously assumed; in other words, at any given time certain of the normoblasts might be in a less, others in a more active state in terms of excessive porphyrin production. If this were true, it would be anticipated that the greater the stimulus to hemoglobin synthesis, the more manifest the enzymatic abnormality and accumulation of UP I and CP I. This, in effect, suggested that an additional stimulus to erythropoiesis might result in a much higher proportion of fluorescing normoblasts than that observed in the animal's basic state. It was postulated in earlier papers $(2,8)$ that the marked reduction of erythrocyte, urinary and fecal porphyrin concentrations after splenectomy in human erythropoietic porphyria was due to removal of the stimulus to erythropoiesis provided by excessive hemolysis. WASS and Schwartz (12) noted that bleeding

3) These abbreviations include both porphyrins and chromogens, it being recognized that biogenesis proceeds only.over the porphyrinogens. In the isolations and analyses to be described, however, the latter are included with the porphyrins. of porphyric animals was shortly followed by marked increases of UP and CP in the circulating red cells. In one animal, for example, the withdrawal of three liters of blood was followed within four days by an increase of the erythrocyte UP from $2.9 \mu \mathrm{g} / 100 \mathrm{~m} l$ to $142 \mu \mathrm{g} /$ $100 \mathrm{~m} l$. In a separate communication with W. RUNGE (13) a study is described in which porphyric and normal animals were bled sufficiently to stimulate erythropoiesis, the percentage of fluorescing normoblasts in the bone marrow being determined before and after bleeding. The uniform increase to from $80-90 \%$ appears more in accord with the unimodal concept, at least insofar as the bovine disease is concerned.

If the bimodal concept were correct it would be logical to anticipate that the presumably short-lived uroporphyrin rich cells would regularly provide a hemolysate representative of the genetic abnormality, i.e., preponderance of type I porphyrin formation, while hemolysates prepared from the osmotically less fragile cells of greater density might be expected to convert PBG to isomer III. At the same time it is recognized that even with a unimodal distribution some difference in this respect might well be due simply to the relative maturity of the cells. represented in these fractions but it is unlikely that the difference would be as great or as consistent as would be anticipated with a bimodal distribution. Experiments designed to study this question have now been carried out and are described in the following.

\section{Material and Methods}

Eleven experiments have been completed with hemolysates from bovine (exps. 1-11, incl.) and two from human porphyric blood (exps. 12, 13) with appropriate controls. Tables $1-13$ are numbered accordingly.

The porphyric animals studied were homozygous for the bovine erythropoietic porphyria trait, members of a family of purebred Holstein cattle (14). The control animals, with one exception, No. 2121 (see below) had no known relationship to the porphyrics, and their erythrocyte porphyrin values were normal as contrasted with the marked or significant elevations in the porphyric animals, as will be noted in the Tables (see Results).

Hemolysates for incubation with PBG were prepared by lysis with distilled water or hypotonic saline solutions, using total red cells or fractions obtained either by differential centrifugation or differential osmotic lysis. In all experiments the red cells were washed twice with cold physiological saline prior to hemolysis. In exps. 1 and 2 , the phosphate buffer $-\mathrm{KCl}$ mixture $\left(0.15 \mathrm{M} \mathrm{KH}_{2} \mathrm{PO}_{4} /\right.$ $\mathrm{Na}_{2} \mathrm{HPO}_{4} \mathrm{pH} 7.4$, containing $0.483 \mathrm{M} \mathrm{KCl}$ ) was prepared according to the earlier method of DRESEL and FALK (15). In all other experiments, bovine and human, the later method of DrESEL and FALK (16) was used, consisting of dilution of the hemolysate to isotonicity by adding $0.604 \mathrm{M} \mathrm{KCl}$. The quantitative relationships were in the ratio of 1.0 red cells: $2.0 \mathrm{H}_{2} \mathrm{O}: 0.5$ of $0: 604 \mathrm{M} \mathrm{KCl}$ and 2.2 of $0.122 \mathrm{M} \mathrm{KCl}$. In run 4 , exp. 9, the Tris buffer mixture, as employed by VAVRA and co-workers (17) was compared with the $\mathrm{KCl}$ diluent. The Tris buffer mixture was composed as follows: $1 \mathrm{ml}$ of $2.1 \% \mathrm{NaCl}, 5 \mathrm{ml} 0.1 \mathrm{M}$ Tris buffer, $1.3 \mathrm{ml} 0.604 \mathrm{M} \mathrm{KCl}$, $1.0 \mathrm{ml} 0.122 \mathrm{M} \mathrm{KCl}$ and $1.8 \mathrm{ml} 0.85 \% \mathrm{NaCl}$.

In separating erythrocytes on the basis of density, the cells were packed at 2000 RPM for 30 minutes at $4^{\circ}$ after which the upper and lower quarters were removed separately, each being resuspended and recentrifuged, the upper and lower quarters again being obtained. The PBG in the amounts noted in the Tables was dissolved in the phosphate buffer $-\mathrm{KCl}$ mixture (exps. 1 and 2) or the 


\section{Plasmaprotein- Antisera Behringwerke

Qualitative und quantitative immunologische Bestimmung von Plasmaproteinen

Bluteiweiß-Differentialdiagnostik durch einfache Immunpräzipitations-Methoden

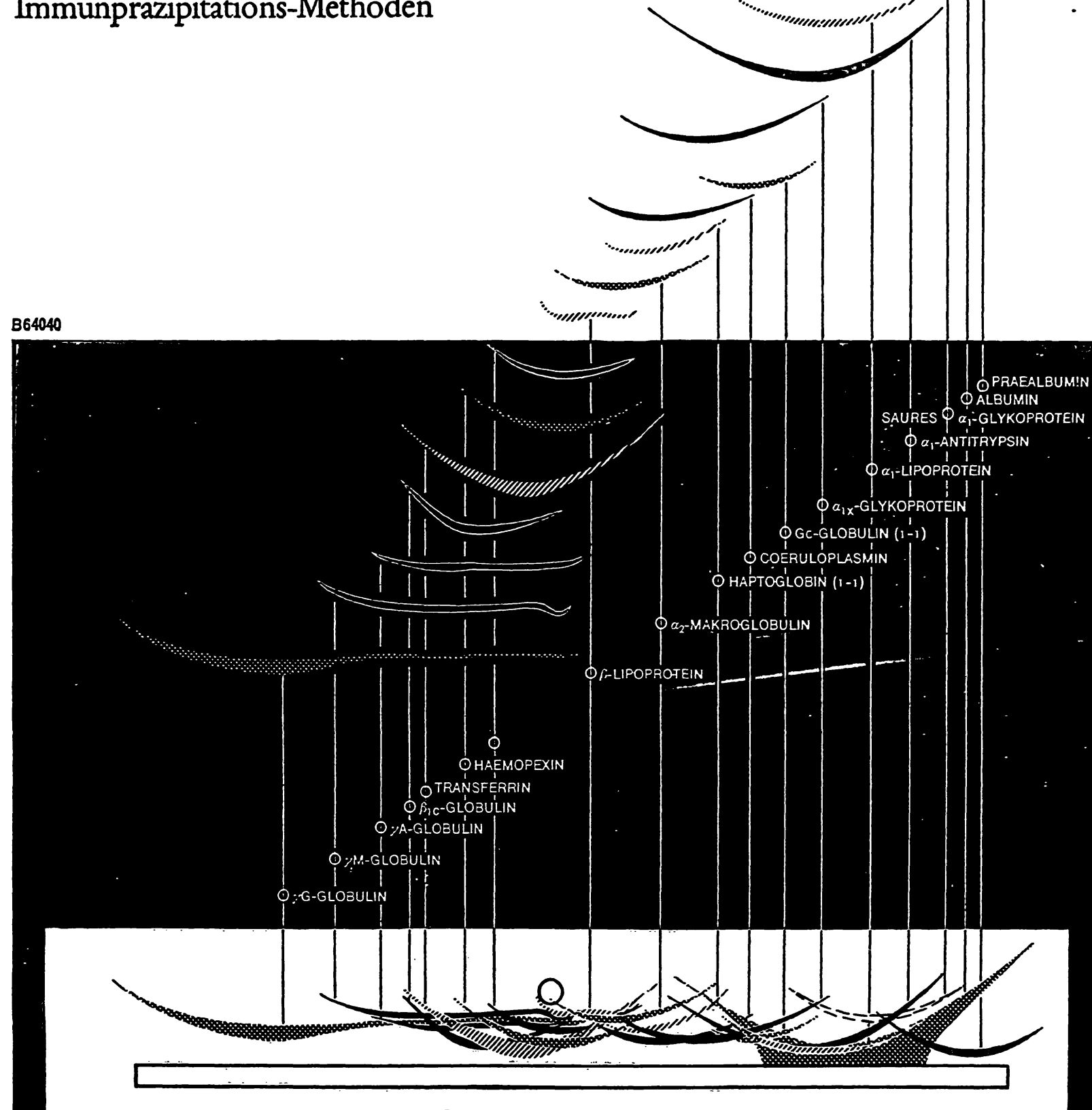


Jetzt von SIGMA selbst hergestellt

\section{6-Phosphogluconsäure-Dehydrogenase}

\author{
aus Hefe
}

Kristallsuspensionen in Ammoniumsulfat

Eine Einheit oxydiert ein $\mu \mathrm{Mol}$ 6-Phosphogluconat pro Minute bei $\mathrm{pH} 7,4$ und $37^{\circ}$

\section{Typ VI, krisțallin}

Aktivität: etwa 50 Einheiten pro $\mathrm{mg}$. Keine Fremdaktivitäten an Hexokinase, Glucose-6-phosphat-Dehydrogenase und Phosphoriboisomerase.

25 Einheiten $\$ 13,50$

100 Einheiten $\$ 45,00$

500 Einheiten $\$ 150,00$

250 Einheiten $\$ 90,00$

1000 Einheiten \$250,00

\section{Typ V, kristallin}

Aktivität: efwa 50 Einheiten pro $\mathrm{mg}$

Fremdaktivitäten: Hexokinase $<0,1 \%$

Glucose-6-phosphat-Dehydrogenase $<0,1 \%$

25 Einheiten $\$ 12,00$

100 Einheiten $\$ 40,50 \quad 500$ Einheiten $\$ 135,00$

250 Einheiten $\$ 81,00 \quad 1000$ Einheiten $\$ 225,00$

\section{Typ IV, kristallin}

Aktivität: etwa 20 Einheiten pro $\mathrm{mg}$

Fremdaktivitäten: Hexokinase $<2 \%$

Glucose-6-phosphat-Dehydrogenase $<0,1 \%$

25. Einheiten $\$ 10,00 \quad 100$ Einheiten $\$ 32,00$

500 Einheiten $\$ 108,00$

Wie bereits angekündigt, stellen wir jetzt auch her:

Enolase

Glucose-6-phosphat-Dehydro-

genase

Kreatin-Phosphokinase

Lactat-Dehydrogenase

Phosphoglucomułase

Phosphohexose-Isomerase

Glyoxalase

Hexokinase

Katalase

Phosphoriboisomerase

Phosphoribulokinase

Pyruvat-Kinase

\section{ANLEITUNGEN KOSTENLOS ERHÄLTLICH}

Die nachstehenden Verfahren, die ursprünglich für Bestimmungen im Serum oder Urin veröffentlicht wurden, eignen sich hervorragend auch für Forschungsarbeiten.

Aldolase im Serum $(540 \mathrm{~nm})$ Bulletin 750

Amylase in Serum und Urin, visuelles Verfahren, Bulletin 700

Chlorid in Serum oder anderen biologischen Flüssigkeiten, titrimetrisch, Bulletin 830

reatinphosphokinase (CPK) im Serum, kolorimetrisch $(500-540 \mathrm{~nm})$ Bullefin 520

Kreatinphosphokinase (CPK) im Serum, unter Verwendung von Sulfhydrylgruppen, kolorimetrisch (um $660 \mathrm{~nm}$ ) Bulletin 661

Kreatinphosphokinase (CPK) im Serum, UV-Test (340 $\mathrm{nm}$ ) Bulletin 40-UV

Cytochromoxydase, histochemisch, Bulletin 185

Athylalkohol in Blut und Serum, enzymatisch $(340 \mathrm{~nm})$ Bulletin 330-UV

Formimino-L-Glutaminsäure (FIGLU), im Harn $(365 \mathrm{~nm})$ Bulletin 365-UV

Galakfose-1-phosphat-Uridyl-Transferase, für die Diagnose der Galakłosämie $(340 \mathrm{~nm}$ ) Bulletin 600-UV Glucose in Blut und Serum $(540 \mathrm{~nm}$ ) Bulletin 14

dasselbe Filtral kann für die Bestimmung des Harnstoff-N verwendet werden

Glucose im Plasma, enzymatisch kolorimetrisch (490 bis $510 \mathrm{~nm}$ ) Bulletin 510

Glucose-6-phosphat-Dehydrogenase in Erythrocyten, sehr einfache visuelle Methode, erfordert kein Instrument, Bulletin 400

$\alpha$-Hydroxybuttersäure-Dehydrogengse im Serum, kolorimetrisch (um $500 \mathrm{~nm}$ ) Bulletin 495

im Serum, Hydroxybutfersäure-Dehydrogenase Bulletin 20-UV

osphor, anorganischer in Serum und Urin, kolorimetrisch (um 620-700 nm) Bulletin 670

Isocitrat-Dehydrogenase im Serum, kolorimetrisch $(340 \mathrm{~nm}) ;$ UV-Test $(340 \mathrm{~nm})$ Bulletin 175/150-UV

L-(+)-Lactat im Blut, enzymatisch $(340 \mathrm{~nm})$ Bulletin 825-UV

Lactat-Dehydrogenase in Serum und Harn einschl: der Isoenzyme $(400-550 \mathrm{~nm})$ Bulletin 500

Lactat-Dehydrogenase im Serum $(340 \mathrm{~nm})$ Bulletin 340-UVे

Leucin-Aminopeptidase im Serum $(580 \mathrm{~nm})$ Bulletin 250 Lipase im Serum, titrimetrisch, Bulletin 800

Malat-Dehydrogenase im Serum $(340 \mathrm{~nm})$ Bulletin 340-UV

Ornithin Transcarbamylase (OCT) im Serum, erfordert Ammoniakbestimmung, Bulletin 108 fluylalanin in Serum

Paure in Blutaussitrichen und , Bulletin 85

osphatase im Serum, alkalische, saure und Prostatasowie im Harn, alkalische $(410 \mathrm{~nm})$ Bulletin 104

$(490 \mathrm{~nm})$ Bulletin 650

yruvat in Blut, Plasma und anderen Flüssigkeiten, enzymatisch $(340 \mathrm{~nm})$ Bulletin $725-U V$

Sorbit-Dehydrogenase (SDH) im Serum, UV-Test $340 \mathrm{~nm}$ ) Bulletin 50-UV

Transaminasen (GOT U. GPT) im Serum (505 nm) Bulletin 505

Transaminasen (GOT U. GPT) im Serum (340 nm) Bulletin 410-UV

Harnstoff- $N$ in Blut oder Serum $(400-420 \mathrm{~nm})$ Bulletin 14 dasselbe Filtrat kann für die Glucösebestimmung verwendet werdeñ

Harnsäure im Serum, enzymatisch $(650-750 \mathrm{~nm})$ Bulletin 680

Vanillinmandelsäure (VMA) im Harn, kolorimetrisch $(470-510 \mathrm{~nm})$ Bulletin 480

Sigma-Reagenzien sind in der ganzen Welt durch den Fachhandel oder direkt aus St. Louis beziehbar.

Telegramme: SIGMACHEM, St. Louis, Missouri

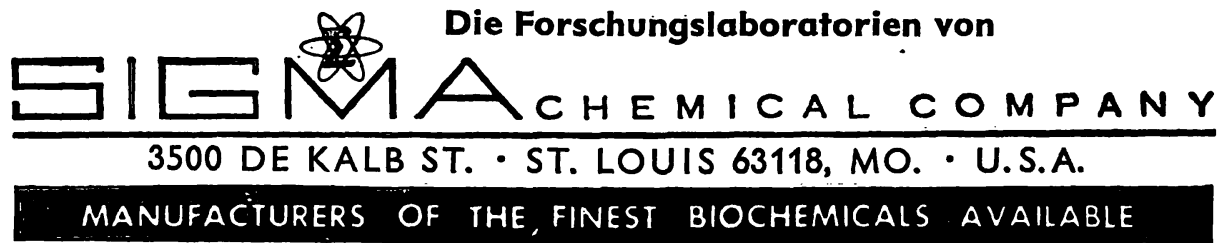

Vertrefung in Éngland: 
isotonic $\mathrm{KCl}$ solution (exps. 3-13). The PBG used was crystallized from the urine of paticnts having acute porphyria in relapse or remission, by the method of Cookson and Rimincton (18). The sample of PBG was weighed in exps. 1 and 2 , in the others being determined beforc and after incubation, after precipitation of protein with trichloroacetic and application of the Ehrlich reaction, as previously described (19). The solutions, in flasks plugged loosely with cotton, were incubated at $37^{\circ}$ for periods ranging from $2-8$ hours at a rate of $90-100$ shakes/minute. Control runs were made with packed cells from normal bovine or human blood. The control used in exps. 5 and 7 was from animal No. 2121, a heterozygote, on the basis of the breeding record. It has not been possible thus far to detect the heterozygous condition on the basis of porphyrin analyses, whether of blood, bonc marrow, or urine. Controls were run without added PBG, or without hemolysate.

The bovine reticulocytes were counted by the method of TODD and coworkers (20). As will be noted, the counts in the normal bovines were usually 0 , in accord with previous reports (21). At times there was an increase of cells staining diffusely blue, without substantia reticulofilamentosa, but believed to represent equivalent forms (see Table 9, below).

In experiment 1 , differential osmotic lysis was carried out at $4^{\circ}$ with $120 \mathrm{~m} /$ of packed red cells from $580 \mathrm{~m} /$ of blood of porphyric cow No. 1589 . The total cells contained $3.5 \%$ reticulocytcs. Three hemolysates, A, B and C, were prepared from the entire sample hemolyzed in sequence for $3 / 4 \mathrm{~h}$ each at $0.6,0.52 \% \mathrm{NaCl}$ and distilled water. Amounts of hemolysate, in terms of equal hemoglobin content $(0.29 \mathrm{gms} \mathrm{Hb}$ in each) were adjusted with $10 \%$ saline to a final concentration of $0.6 \%$ after which $10 \mathrm{ml}$ of the phosphate buffer - $\mathrm{KCl}$ mixture (sce above) containing $1 \mathrm{mg}$ of PBG was added to each and to the control, the latter composed of the saline-buffer-PBG mixturc without hemolysate.

Exps. 2-6, incl., were carried out with blood from the bovine porphyric No. 2120. Exps. 2, 3, 6, 8, 9, 10 and 12 included observations on hemolysates obtained after differential centrifugation of red cells, while in cxps. 4, 5, 7,11 and 13, only total exythrocytes were hemolyzed. In exp. 5 the possible effect of GSH and AMP on the amount and type of free porphyrins formed from PBG, was examined. In each of six runs $10 \mathrm{~m} /$ of packed cells were used, laked with $20 \mathrm{~m} /$ distilled water. GSH was added to give a final concentration of $0.01 \mathrm{M}$ in runs 3 and 4 , and AMP to a final concentration of $0.003 \mathrm{M}$ in runs 5 and 6 . In cach instance these substances were dissolved in $5 \mathrm{~m} /$ of $0.604 \mathrm{M} \mathrm{KCl}$. To this was added $22 \mathrm{ml}$ of $0.122 \mathrm{M} \mathrm{KCl}$ with the dissolved PBG.

Although the amounts of UP, CP and Proto- were determined before and after incubation in all experiments, no data were obtained as to amounts of heme which might have been formed. In exp. 7 (Tab. 7) the effect of variations in $\mathrm{K}$ and $\mathrm{Na}$ concentration was studied in relation to porphyrin formation and isomer ratio. This was done in view of the variable but relatively high content of $\mathrm{NaCl}$ in bovine erythrocytes (22). Ten $\mathrm{m} /$ packed cells of porphyric (2955) and heterozygous (2121) bovines were used in each run. One run from each animal was made with the $\mathrm{KCl}$ diluent (see above) and one with an isotonic concentration of $\mathrm{NaCl}$ and $\mathrm{KCl}(2: 1)$.

In the earlier experiments, Nos. $1-5$, incl., the initial transport and handling of blood and hemolysates was at ambient temperaturc except that the fractional centrifugations were carried out in a refrigerated centrifuge at $4^{\circ}$. In these the interval was considerably longer than in the later bovine and human experiments as the bleeding of the bovines was done at the Veterinary Farm about 20 miles from our laboratory where the samples were subjected to the experiments to be described. This entailed a variable period of exposure to ambient temperature. In exps. $6-11$, incl. the samples were refrigerated in transit except in certain runs to be noted, in which the exposure at ambient temperature was purposely allowed in order to permit comparisons in respect to this factor. In exps. 12 and 13 (human) the exposure to ambient temperature was only brief as the blood was drawn in our laboratory and at once processed.

Exp. 11 was designed to permit comparison of different periods of incubation, in respect to porphyrin formation by normal vs porphyric bovine hemolysates. The blood and hemolysates werc kept cold from collection to incubation. Normal, without added PBG: $45 \mathrm{~m} /$ of packed normal red cells (Hamilton No. 1 cow) werc hemolyzed and diluted according to the above ratio. The hemolysate was divided in three equal parts, the first being frozen immediatcly, the second being incubated for four hours and the third for eight hours. Normal, with PBG: $60 \mathrm{~m} /$ packed cells were treated similarly. This hemolysate was divided in four parts which werc incubated for 2, 4, 6 and 8 hours, respectively. The porphyric red cells from cow No. 2955 were studied in the same way.

Exps. 12 and 13 were carricd out with human porphyric blood obtained, respectively, from cascs \# 71, (D. H., ? 24), \# 76 (M. H. $₹$ age 15) and \#265 (T. H. $\{$ age 7). The casc numbers rclate to our general porphyria rostcr. Case 76 , first described in 1954 (2), has shown the characteristic photosensitivity, hydroa and epidermolysis, hirsutism, reddish brown tecth and red urinc. Case 265 is the younger sister of our first case of erythropoictic porphyria, D. H., \#71 $q$ who is now 24 and in remarkably good health, having been splenectomized at age 4 (23). T. H. first devcloped evidence of photosensitivity and red urine at age 2. The father of these girls is dead, the mother living and well. There is no history of consanguinity nor of photosensitivity in the parents or other members of the family. There are three older siblings, all of whom have been examined with respect to physical or biochemical abnormality (urine, fecal and erythrocyte porphyrins). No evidence of porphyria has been found.

Fractional determination of UP, CP and Proto- of red cells or hemolysates from all experiments was carried out by the methods previously used in this laboratory $(24,25)$. The native free porphyrins and the $C P$ obtained by decarboxylation of UP, were subjected to prcliminary purification by $\mathrm{Al}_{2} \mathrm{O}_{3}$ chromatography, after which the respective methyl esters were chromatographed on either $\mathrm{CaCO}_{3}$ or $\mathrm{MgO}$ (26). In certain of the bovine samples the UP fraction was difficult to separate from an unidentified green compound and in these repeated chromatography was necessary. Decarboxylation of UP (27) and quantitative paper chromatography of the CP isomers is indicated in the Tables as UP $\rightarrow$ CP. The Eriksen method (28) was used and in addition the Turner "door" fluorometer ${ }^{4}$ ) was employed to determine the proportion of CP isomers $(29,30)$, native or after decarboxylation of UP. In the later experiments of the present serics (Nos. 6, 8, 9, 10, 11, 13) the UP isomer composition was detcrmined by the CornfordBcnson technique (31) not yet described when the earlicr cxperiments were carried out. According to the authors, their method "detects and estimates ratios of the isomers ranging between $17: 83$ and 100:0 (I:III) with 7\%, accuracy". In exps. 6 and 8 , both this method and decarboxylation were employed. In several experiments (Nos. 5-8, incl., and 10) the Proto- of the hemolysate, after incubation and scparation from $C P$ and UP, was converted to Meso- by catalytic hydrogenation with palladium, followed by paper chromatography. The essential features of this method have been described in an carlicr report (4).

In general no attempt has been made to render an accurate account on a molar basis of the net differences of both PBG and total porphyrin, before and after incubation. Since the important relationship is that between PBG und UP this calculation first entails conversion of the amounts of $\mathrm{CP}$ and Proto- on the basis of their molecular weights to the equivalent amount of UP (Proto\% 1.4 or $C P \times 1.3=$ UP equivalent). This may then be expressed in $\mu \mathrm{M}$ net increase of total porphyrin, as in the sample calculations for the porphyric and normal subjects in Tables 12 and 13. To permit comparison of the net increase of CP I and UP I in relation to isomer III, as in Tables 6,8,9 and 10, the amount of each is calculated on the basis of the corresponding \% 1 in the columns on the right, the amount of CP I is then calculated and converted to UP I by the factor 1.3.

Whenever it has appeared helpful in relating procedure to results, additional details of the individual experiments are included in the Tables, undex Results.

4) G. K. Turner Associates, Palo Alto, California. 


\section{Results}

In the following description of results, special attention will be given to the utilization or disappearance of PBG, the quantities of porphyrins and proportion of UP and CP isomers I and III, and the amount and identity of the Proto-, formed in the various hemolysates after incubation with PBG, as described in the foregoing.

The essential data, including certain items of protocol related to the individual experiments, are presented in Tables 1-13, incl.

The hemolysates of the more fragile porphyric red cells obtained by fractional osmotic lysis utilized more PBG and formed larger amounts of total and individual porphyrins (Tab. 1).

Tab. 1

Exp. 1 (9-23-59). Four hour incubation of PBG (1 $\mathrm{mg}$ in each run) in hemolysates obtained by differential osmotic lysis of red cells from porphyric animal No. 1589 (retic. $3.5 \%$ )

\begin{tabular}{|c|c|c|c|c|c|}
\hline \multirow[b]{2}{*}{ Run } & \multirow[b]{2}{*}{ Fractional hemolysis } & \multicolumn{3}{|c|}{$\begin{array}{l}\mu \mathrm{g} \text { porphyrins } \\
\text { (Pre-incubation values } \\
\text { in parenthesis) }\end{array}$} & \multirow[t]{2}{*}{$\begin{array}{l}\text { UPP\% I } \\
\left(\mathrm{UP}_{\mathrm{CP}}\right)\end{array}$} \\
\hline & & Proto- & CP & UP & \\
\hline 1 & $\begin{array}{l}\text { Hemolysate } \mathrm{A} \\
\text { (hemol. at } 0.6 \% \mathrm{NaCl} \text { ) }\end{array}$ & $\begin{array}{l}18.0 \\
(6.7)\end{array}$ & $\begin{array}{l}34.5 \\
(1.5)\end{array}$ & $\begin{array}{c}92.0 \\
(21.8)\end{array}$ & $70 \%$ \\
\hline 2 & $\begin{array}{l}\text { Hemolysate } \mathrm{B} \\
\text { (remainder at } 0.52 \% \mathrm{NaCl} \text { ) }\end{array}$ & $\begin{array}{l}9.6 \\
(6.4)\end{array}$ & $\begin{array}{l}10.7 \\
(0.6)\end{array}$ & $\begin{array}{l}54.0 \\
(5.6)\end{array}$ & * \\
\hline 3 & Hemolysate $\mathrm{C}$ & 6.2 & 3.9 & 19.0 & $70 \%$ \\
\hline 4 & Control (PBG only) & 0 & 0 & 0.09 & \\
\hline
\end{tabular}

*) Sample destroyed during decarboxylation

\section{Utilization or disappearance of PBG}

It is evident in Tables 2-12, incl., that there was greater utilization of PBG and formation of porphyrin, by porphyric as compared with heterozygous or normal hemolysates. In the case of the hemolysate from the heterozygous bovine \#2121 (Tab. 7) the differences were not great and the amount of UP observed after incubation was actually greater, although interestingly enough, the Proto- was signifiçantly greater in the homozygous hemolysate. In Table 13 no significant difference is evident in the total porphyrins as between porphyric, probable heterozygous and normal hemolysates.

The same type of differences is often observed with the lesser as contrasted with greater density cells (1. d. c. and g. d. c., respectively), (Tab. 2, 3, 8, 10). In exp. 6 (Tab. 6) opposite differences of minor degree are seen but here the separation of reticulocytes was of questionable significance. In exp. 9 (Tab. 9), the normal bovine cell hemolysates in the comparable runs 3 and 6 , before and after bleeding, respectively, produced similar amounts of porphyrin despite a significantly greater disappearance of the added PBG in run 6. It is clear that disappearance of PBG is not necessarily related to porphyrin formation although in the porphyric hemolysates generally more than $50 \%$ was thus accounted for. The extent to which the fraction unaccounted for relates to heme formation or conversion of PBG to porphobilin has not been determined. (The question of $\mathrm{pH}$ effect is discussed below). Studies ${ }^{5}$ ) with $\delta$-aminolevulinic acid-[4-14 C] (ALA- $\left[4-{ }^{14} \mathrm{C}\right]$ ) in normal and porphyric hemolysates; carefully protected against heat

5) With S. Schwartz and I. Bossenmaier, unpublished.

Tab. 2

Exp. 2 (12-2-59). Eight hour incubation of PBG in hemolysates obtained by differential centrifugation of bovine porphyric red cells

\begin{tabular}{|c|c|c|c|c|c|c|c|c|c|c|c|}
\hline Run & Source and type of cells & $\begin{array}{c}\text { Reticulo- } \\
\text { cytes } \\
\%\end{array}$ & $\begin{array}{c}\mathrm{ml} \\
\text { packed } \\
\text { cells }\end{array}$ & $\begin{array}{c}\mathrm{ml} \\
\text { dist. } \\
\mathrm{H}_{2} \mathrm{O}\end{array}$ & $\begin{array}{c}\mathrm{ml} \\
\text { buffer }\end{array}$ & $\begin{array}{l}\text { mg. } \\
\text { PBG } \\
\text { added }\end{array}$ & $\begin{array}{l}\text { (pre- } \\
\text { Proto- }\end{array}$ & $\begin{array}{l}\text { porphyrins } \\
\text { cubation va } \\
\text { arentheses) } \\
\text { CP }\end{array}$ & $\begin{array}{l}\text { lues in } \\
\text { UP }\end{array}$ & $\begin{array}{c}\text { UP } \% \text { I } \\
(U P P \rightarrow C P)\end{array}$ & $\begin{array}{l}\text { Net } \\
\text { increase } \\
\text { UP I } \mu \mathrm{g}\end{array}$ \\
\hline $\begin{array}{l}1 \\
2 \\
3 \\
4 \\
5\end{array}$ & $\begin{array}{l}\text { Porphyric \#2120, l. d. c. } \\
\text { Porphyric \#2120, g. d. c. } \\
\text { Normal \# } 1913, \text { t. c. } \\
\text { Control, no cells } \\
\text { Control, no cells }\end{array}$ & $\begin{array}{r}82.4 \\
8.2 \\
<0.5 \\
=\end{array}$ & $\begin{array}{l}1.0 \\
1.0 \\
5.0 \\
0 \\
0\end{array}$ & $\begin{array}{l}15 \\
15 \\
75 \\
75 \\
15\end{array}$ & $\begin{array}{r}5 \\
5 \\
25 \\
25 \\
5\end{array}$ & $\begin{array}{l}0.4 \\
0.4 \\
1.0 \\
1.0 \\
0.4\end{array}$ & $\begin{array}{l}51(3) \\
22(6) \\
9 * \\
0.2 \\
0\end{array}$ & $\begin{array}{l}36(24) \\
14(.4) \\
8^{*} \\
0.1 \\
0.3\end{array}$ & $\begin{array}{l}198(74) \\
138(3.2) \\
39 * \\
18 \\
21\end{array}$ & $\begin{array}{l}76 \\
60 \\
=\end{array}$ & $\begin{array}{l}94 \\
81\end{array}$ \\
\hline
\end{tabular}

* Pre-incubated values not determined

Tab. 3

Exp. 3 (8-24-60). Utilization or disappearance of PBG in hemolysates of greater and lesser density porphyric vs normal erythrocytes. Samples of packed cells from bovine porphyric $(P)$ \# 2120 , and bovine normal $(N)$ \# 1756 hemolyzed and incubated for eight hours

\begin{tabular}{|c|c|c|c|c|c|c|c|c|}
\hline Run & $\begin{array}{l}\text { Descrip- } \\
\text { tion }\end{array}$ & $\begin{array}{c}\text { Reticulocytes } \\
\%\end{array}$ & $\begin{array}{l}\mathrm{m} l \text { packed } \\
\text { cells }\end{array}$ & Added & ${ }^{\text {mg }}{ }_{\text {Remaining }}$ & $\begin{array}{c}\text { (pre- } \\
\text { Proto- }\end{array}$ & $\begin{array}{l}\text { orphyrins } \\
\text { n values i } \\
\text { CP }\end{array}$ & $\begin{array}{l}\text { theses) } \\
\text { UP }\end{array}$ \\
\hline $\begin{array}{l}1 \\
2 \\
3 \\
4 \\
5 \\
6\end{array}$ & $\begin{array}{l}\text { N., t. c. } \\
\text { N., l. d. c. } \\
\text { N., g. d. c. } \\
\text { P., t. c. } \\
\text { P., l. d. c. } \\
\text { P., g. d. c. }\end{array}$ & $\begin{array}{l}0 \\
0 \\
0 \\
3.3 \\
5.5 \\
1.9\end{array}$ & $\begin{array}{l}4.0 \\
2.0 \\
2.0 \\
4.0 \\
2.0 \\
2.0\end{array}$ & $\begin{array}{l}2.91 \\
1.95 \\
1.93 \\
2.90 \\
1.92 \\
1.97\end{array}$ & $\begin{array}{l}2.09 \\
1.32 \\
1.37 \\
0.38 \\
0.30 \\
0.84\end{array}$ & $\begin{array}{r}19(2.0) \\
17(1.0) \\
12(1.5) \\
139(7.0) \\
115(4.5) \\
65(6.0)\end{array}$ & $\begin{array}{c}38(0) \\
56(0) \\
18(0) \\
419(2.7) \\
134(6.0) \\
73(0.9)\end{array}$ & $\begin{array}{l}114(0) \\
100(0) \\
88(0) \\
723(21) \\
640(28) \\
257(9.0)\end{array}$ \\
\hline
\end{tabular}

Tab. 4

Exp. 4 (10-4-61). Utilization or disappearance of PBG, amounts and types of porphyrin isomers formed with normal vs porphyric bovine hemolysates of total cells, eight hour incubation

\begin{tabular}{|c|c|c|c|c|c|c|c|c|c|}
\hline \multirow[b]{2}{*}{ Run } & \multirow[b]{2}{*}{ Source of cells } & \multirow{2}{*}{$\begin{array}{l}\mathrm{ml} \text { packed } \\
\text { cells used }\end{array}$} & \multicolumn{2}{|c|}{ mg PBG } & \multicolumn{3}{|c|}{$\begin{array}{l}\mu \mathrm{g} \text { porphyrins } \\
\text { (pre-incubation values in parentheses) }\end{array}$} & \multirow{2}{*}{$\mathrm{CP}$} & \multirow{2}{*}{$\begin{array}{l}\text { \% type I UP } \\
\qquad(U P \rightarrow C P)\end{array}$} \\
\hline & & & Added & Remaining & Proto- & $\mathrm{CP}$ & UP & & \\
\hline $\begin{array}{l}1 \\
2 \\
3\end{array}$ & $\begin{array}{l}\text { Normal \# } 1756 \\
\text { Porphyric \#2120 } \\
\text { Control - no cells }\end{array}$ & $\begin{array}{l}9.0 \\
9.4 \\
0\end{array}$ & $\begin{array}{l}2.77 \\
3.07 \\
1.88\end{array}$ & $\begin{array}{l}1.58 \\
0.30 \\
1.09\end{array}$ & $\begin{array}{c}21(6) \\
136(29) \\
0.2\end{array}$ & $\begin{array}{r}26(0) \\
214(7) \\
0.2\end{array}$ & $\begin{array}{l}162(0) \\
702(33) \\
35\end{array}$ & $\begin{array}{l}45 \\
85 \\
-\end{array}$ & $\begin{array}{r}80 \\
100 \\
65\end{array}$ \\
\hline
\end{tabular}


Tab. 5

Exp. 5 (12-20-62). Utilization or disappearance of PBG on eight hour incubation of hemolysates of red cells from porphyric \# 2120 (retic. 12 \%) vs heterozygous \#2121 (retic. 0); amounts and types of porphyrin isomers formed; effect of GSH and AMP (see Methods); $10 \mathrm{ml}$ packed cells in each hemolysate

\begin{tabular}{|c|c|c|c|c|c|c|c|}
\hline Run & \multicolumn{2}{|c|}{ Added $^{\mathrm{mg}} \stackrel{\mathrm{PBg}}{\text { Remaining }}$} & \multicolumn{3}{|c|}{$\begin{array}{l}\text { Mg porphyrins } \\
\text { (pre-incubation values in parentheses) } \\
\text { Proto- } \quad \text { CP }\end{array}$} & \multicolumn{2}{|c|}{$\underset{C P}{\text { Porphyrin isomers, }} \stackrel{\text { UP }}{\text { "1" I }} \rightarrow C P$} \\
\hline $\begin{array}{l}\text { PBG only } \\
1 \text { \#2120 } \\
2 \text { \#2121 } \\
\\
\text { Control, no cells }\end{array}$ & $\begin{array}{l}4.39 \\
2.5 \\
1.01\end{array}$ & $\begin{array}{l}0.25 \\
1.2 \\
0.79\end{array}$ & $\begin{array}{l}365 *(35) \\
42 *(6) \\
0\end{array}$ & $\begin{array}{c}257(7) \\
19(0) \\
0\end{array}$ & $\begin{array}{c}1008(52) \\
280(0) \\
3.0\end{array}$ & $\begin{array}{l}81 \\
95 \\
-\end{array}$ & $\begin{array}{r}100 \\
83 \\
-\end{array}$ \\
\hline $\begin{array}{l}\text { PBG and } .01 \mathrm{M} \text { GSH } \\
3 \quad \# 2120 \\
4 \quad \# 2121\end{array}$ & $\begin{array}{l}4.4 \\
2.4\end{array}$ & $* *$ & $\begin{array}{r}97 \\
6\end{array}$ & $\begin{array}{l}72 \\
11\end{array}$ & $\begin{array}{l}43 \\
14\end{array}$ & $\begin{array}{l}97 \\
95\end{array}$ & $\frac{98}{-}$ \\
\hline $\begin{array}{l}\text { PBG and } .003 \mathrm{M} \text { AMP } \\
5 \quad \# 2120 \\
6 \quad \# 2121\end{array}$ & $\begin{array}{l}4.5 \\
2.4\end{array}$ & $\begin{array}{l}0.79 \\
1.58\end{array}$ & $\begin{array}{r}238^{*} \\
64^{*}\end{array}$ & $\begin{array}{r}338 \\
21\end{array}$ & $\begin{array}{r}626 \\
96\end{array}$ & $\begin{array}{l}91 \\
95\end{array}$ & $\begin{array}{l}95 \\
93\end{array}$ \\
\hline
\end{tabular}

* Proto- to Meso-, all type 9 (III)

** PBG determination prevented due to rapid fading of color caused by GSH

Tab. 6

Exp. 6 (6-25-63). Effect of temperature variations prior to incubation, on utilization or disappearance of PBG and on porphyrin formation by porphyric (\#2120) and normal (\#2126) bovine hemolysates (15 ml packed cells in each run, hemolyzed as described under Methods, and incubated three and one-half hours)

\begin{tabular}{|c|c|c|c|c|c|c|c|c|c|c|c|c|c|c|}
\hline \multirow{2}{*}{ Run } & \multirow{2}{*}{ Animal } & \multirow{2}{*}{ Type } & \multirow{2}{*}{$\begin{array}{c}\text { Cells } \\
\text { heniol. }\end{array}$} & \multirow{2}{*}{$\begin{array}{l}\text { Reticu- } \\
\text { locytes } \\
\%\end{array}$} & \multirow{2}{*}{$\begin{array}{l}\text { Preincu- } \\
\text { bation } \\
\text { temp. }{ }^{\circ} \mathrm{C}\end{array}$} & \multirow[b]{2}{*}{$\begin{array}{l}\text { mg } \\
\text { Added } \\
\text { to he- } \\
\text { moly- } \\
\text { sate }\end{array}$} & \multirow[b]{2}{*}{$\begin{array}{l}\text { PBG } \\
\text { Remaj- } \\
\text { ning } \\
\text { after } \\
\text { incuba- } \\
\text { tion }\end{array}$} & \multirow{2}{*}{\multicolumn{3}{|c|}{$\begin{array}{l}\mu \mathrm{g} \text { porphyrins (preincu- } \\
\text { bation values in parentheses) } \\
\text { Proto- } \quad \mathrm{CP} \quad \text { UP }\end{array}$}} & \multirow{2}{*}{$\begin{array}{l}\text { Net } \\
\text { increase } \\
\mu \text { Mg } \\
\text { UP I + } \\
\text { CP I }\end{array}$} & \multicolumn{3}{|c|}{ Isomer data } \\
\hline & & & & & & & & & & & & $\stackrel{C P}{\% 1 \text { or } 111}$ & UP. B. & $\underset{\mathrm{CP}}{\operatorname{oor}} \underset{\mathrm{UP}}{\mathrm{d!}} \rightarrow$ \\
\hline 1 & 2120 & $\stackrel{P}{P}$ & t. c. & 23.5 & 4 & & & $42(50)$ & $31(28)$ & $104(129)$ & -21 & 1001 & $100 \mathrm{I}$ & 1001 \\
\hline $\begin{array}{l}2 \\
3 \\
4\end{array}$ & $\begin{array}{l}2126 \\
2120 \\
2126\end{array}$ & $\begin{array}{l}N \\
P \\
N\end{array}$ & $\begin{array}{l}\text { t. } c . \\
\text { t. c. } \\
\text { t. c. }\end{array}$ & $\begin{array}{c}0 \\
23.5 \\
0\end{array}$ & $\begin{array}{l}4 \\
4 \\
4\end{array}$ & $\begin{array}{l}0 \\
0.77 \\
0.77\end{array}$ & $\begin{array}{l}0.10 \\
0.25\end{array}$ & $\begin{array}{c}6.6(8.4) \\
175(50) \\
67(8.4)\end{array}$ & $\begin{array}{l}0.3(0.1) \\
91(28) \\
20(0.1)\end{array}$ & $\begin{array}{c}0(0) \\
172(129) \\
53(0)\end{array}$ & $\begin{array}{r}0 \\
125 \\
0\end{array}$ & $\begin{array}{l}100 \overline{1} \\
100 \mathrm{III}\end{array}$ & $\begin{array}{l}1001 \\
100111\end{array}$ & $\begin{array}{l}9 \overline{5} \mathrm{I} \\
88 \mathrm{III}\end{array}$ \\
\hline & & & & & & & & & & & & & cơor & \\
\hline 5 & 2120 & $\mathbf{P}$ & t. c. & 23.5 & $A^{*}+55^{\circ}$ & 0.93 & 0.10 & $151(50)$ & $91(28)$ & $191(129)$ & 144 & $100 I$ & & $95 I$ \\
\hline 6 & 2126 & $\mathbf{N}$ & t. c. & 0 & $A^{*}+55^{\circ}$ & 0.93 & 0.28 & $14(8.4)$ & $6.4(0.1)$ & $90(0)$ & 98 & - & 1001 & $95 \mathrm{I}$ \\
\hline $\begin{array}{r}7 \\
8 \\
9 \\
10\end{array}$ & $\begin{array}{l}2120 \\
2120 \\
2120 \\
2126\end{array}$ & $\begin{array}{l}P \\
P \\
P \\
N\end{array}$ & $\begin{array}{l}\text { l. d. c. } \\
\text { g. d. c. } \\
\text { t. c. } \\
\text { t. c. }\end{array}$ & $\begin{array}{c}30.0 \\
21.0 \\
23.5 \\
0\end{array}$ & $\begin{array}{c}15 \\
4 \\
4 \\
A^{*} \\
A^{*}\end{array}$ & $\begin{array}{l}0.78 \\
0.68 \\
0.79 \\
0.80\end{array}$ & $\begin{array}{l}0.07 \\
0.07 \\
0.07 \\
0.28\end{array}$ & $\begin{array}{c}137 * *(46) \\
125(44) \\
82(50) \\
36(8.4)\end{array}$ & $\begin{array}{c}159(79) \\
75(17) \\
60(28) \\
22(0.1)\end{array}$ & $\begin{array}{l}192(153) \\
116(14) \\
156(129) \\
38(0)\end{array}$ & $\begin{array}{r}143 \\
177 \\
69 \\
-\end{array}$ & $\begin{array}{l}100 I \\
1001 \\
100 I \\
-\end{array}$ & $\begin{array}{l}100 \mathrm{I} \\
100 \mathrm{I} \\
100 \mathrm{I} \\
-\end{array}$ & $\begin{array}{l}100 \text { I } \\
100 \text { I } \\
100 \text { I } \\
\end{array}$ \\
\hline
\end{tabular}

* Ambient ** Proto- to Meso-, all type 9 (III)

Tab. 7

Exp. 7 (10-23-63). Effect of Na vs $\mathrm{K}$ on utilization or disappearance of PBG and formation of porphyrins by porphyric (\# 2955) vs heterozygous (\# 2121) bovine hemolysates; incubation three and one-half hours; $10 \mathrm{ml}$ packed cells in each hemolysate

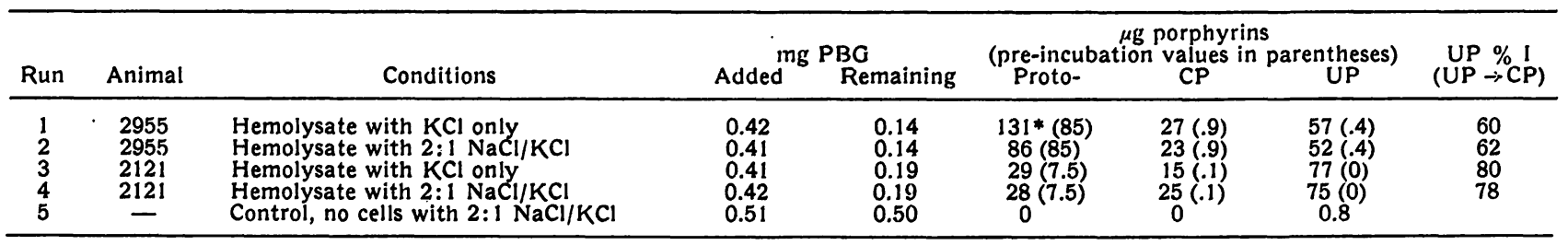

* Proto $\rightarrow$ Meso-, all type 9 (III)

before incubation, indicate that heme formation is small or negligible.

The temperature factor in porphyrin isomer formation

The effect of variation of conditions, especially temperature, in the period between drawing the blood and incubation is highly important as regards isomer distribution. In the present series the effect of exposure to ambient temperatures with or without additional heating at $55^{\circ}$, was first studied in exp. 6, Table 6. Comparison of runs 3 and 4 with 9 and 10 reveal a much smaller total porphyrin formation in the latter in which there was no protection before incubation of the hemolysate. Despite this highly significant difference just as much PBG disappeared in runs 3 and 9 and in runs 4 and 10 .
The possibility is not excluded that the difference is accounted for by greater heme formation in runs 9 and 10. In runs 5 and 6 in which there was additional heat exposure at $55^{\circ}$ for 15 minutes to destroy isomerase activity (38), the much larger amounts of isomer I formed, together with the entirely comparable disappearance of the added PBG suggest that sufficient isomerase may have been active in runs 9 and 10 to produce some Proto- 9 (III) and heme. This could only be determined with labelled substrate and comparable numbers of reticulocytes among the red cells hemolyzed. The plentiful number in run 9 would undoubtedly have supplied both of the mitochondrial enzymes, coproporphyrinogenase and heme synthetase, but in both runs 4 and 10 the normal bovine red cells had no demonstrable reticulocytes, the only difference being in the 
pre-incubation temperature. At the same time it must be noted that in both of these runs a significant amount of new Proto- was formed, at least indicating the presence of some mitochondrial enzyme. Again, this may relate to young cells without the tinctorial properties of reticulocytes (see exp. 9, Tab. 9).

The data in Table 6 reveal an outspoken difference in porphyrin isomer production depending on the preincubation temperature. It is seen that only the normal hemolysate kept at $4^{\circ}$ before incubation exhibited isomer III formation. In the other runs in which the isomer ratio could be determined, only or mainly type I was observed. The 7-COOH "pseudo-uroporphyrin" was noted only once and then in association with type III UP.

In exps. 6-13, incl. (Tab. 6-13), except exp. 12 (Tab. 12), the pre-incubation temperature of the cells and hemolysate was kept at or near $4^{\circ}$, thus the isomer data are undoubtedly much more reliable than in the earlier experiments $1-5$, incl. The data in Table 12 (exp. 12) must be considered individually in this respect as in this instance the (human) blood was drawn in the laboratory and at once processed (see Methods) unlike the bovine bloods in exps. 1-5 which had to be transported a considerable distance during which there was no protection against ambient temperature effect. With the preliminary refrigeration the dominant or at times exclusive formation of isomer III by the normal cell hemolysates is evident and in the same experiments the porphyric hemolysates at the end of incubation contained a major proportion at times only CP I and UP I. Nevertheless significant increases of Proto- 9 (III) are also seen, again revealing the presence of isomerase (Tab. 6 as already discussed; Tab. 8, 9, 10).

\section{Electrolyte, $\mathrm{pH}$ and other factors}

Exp. 7 (Tab. 7) presents comparative data obtained with porphyric vs heterozygous cell hemolysates with special reference to variation in $\mathrm{Na}$ and $\mathrm{K}$ concentration. The porphyric hemolysate in the $\mathrm{KCl}$ diluent had a significant increase in Proto- 9 (III) after incubation, otherwise no effect of the variation in diluent was noted. It was unexpected that the porphyric hemolysate in either diluent contained but $60-62 \%$ of UP. I while the two heterozygous cell hemolysates contained $78-80 \%$ type I. Also, the porphyric hemolysate in the $\mathrm{KCl}$ diluent contained significantly more Proto(all type 9).

Variations in $\mathrm{pH}$ were recorded in exps. 9 and 10 (Tab. 9 and 10). In exp. 9 (normal cell hemolysate) the $\mathrm{pH}$ was somewhat lower in the runs after than those before bleeding. The values are reasonably comparable in runs 3 and 6 before and after bleeding, respectively. These are the only runs which may be compared in terms of similar conditions in other respects, as seen in Table 9. The total porphyrin formed was quite similar but the UP before bleeding was considerably greater while in run 6 Proto- was larger in amount. All of the

Tab. 8

Exp. 8 (2-25-64). Utilization or disappearance of PBG and formation of porphyrin isomers after three and one-half hours incubation of hemolysates prepared from bovine porphyric (No. 2975) and normal (No. 3000) red cells. The porphyric animal had been bled a total of 4.0 liters in

\begin{tabular}{|c|c|c|c|c|c|c|c|c|c|c|c|c|c|}
\hline \multirow{3}{*}{ Run } & \multirow{3}{*}{ Animal } & \multirow{3}{*}{$\begin{array}{l}\text { Type } \\
\text { of } \\
\text { cells }\end{array}$} & \multirow{3}{*}{$\underset{\substack{\mathrm{ml} \\
\text { packed } \\
\text { cells }}}{ }$} & \multirow{3}{*}{$\begin{array}{l}\text { Reti- } \\
\text { culocy- } \\
\text { tes } \\
\%\end{array}$} & \multicolumn{2}{|c|}{$\mathrm{mg}$ PBG } & \multirow{3}{*}{\multicolumn{3}{|c|}{$\begin{array}{l}\mu \text { g porphyrins } \\
\text { (pre-incubation values in parentheses) } \\
\text { Proto- } \quad \text { CP UP }\end{array}$}} & \multirow{3}{*}{$\begin{array}{c}\text { Total net } \\
\text { increase } \mu \mathrm{g} \\
\text { UPI }+ \\
\text { CPI }\end{array}$} & \multicolumn{3}{|c|}{$\%$ Type III } \\
\hline & & & & & \multirow{2}{*}{ Added } & \multirow{2}{*}{ Remaining } & & & & & & & UP \\
\hline & & & & & & & & & & & $\mathrm{CP}$ & C. B. & $\mathrm{UP} \rightarrow \mathrm{CP}$ \\
\hline $\begin{array}{l}1 \\
2 \\
3 \\
4\end{array}$ & $\begin{array}{c}3000 \\
2975 \\
2975 \\
\text { Contro! n }\end{array}$ & $\begin{array}{l}\text { t. c. } \\
\text { l. d. c. } \\
\text { g. d. c. } \\
\text { to cells }\end{array}$ & $\begin{array}{l}15.0 \\
12.0 \\
13.7\end{array}$ & $\begin{array}{l}0 \\
7.7^{*} \\
0.8 * \\
\end{array}$ & $\begin{array}{l}0.96 \\
0.80 \\
0.77 \\
0.8\end{array}$ & $\begin{array}{l}0.33 \\
0.077 \\
0.142 \\
0.62\end{array}$ & $\begin{array}{c}67(7.5) \\
282 * *(54) \\
119 * *(52) \\
0\end{array}$ & $\begin{array}{l}20(0.1) \\
48(1.8) \\
38(0.8) \\
0.3\end{array}$ & $\begin{array}{l}59(0) \\
49(14.6) \\
44(2.0) \\
0.5\end{array}$ & $\begin{array}{r}8 \\
75 \\
37 \\
\end{array}$ & $\begin{array}{l}91 \\
27 \\
71 \\
\end{array}$ & $\begin{array}{r}95 \\
5 \\
50 \\
\end{array}$ & $\begin{array}{l}85 \\
10 \\
42 \\
\end{array}$ \\
\hline
\end{tabular}

* T. C. $2.5 \%$ retic ** Proto- $\rightarrow$ Meso-, all type 9 (III)

Tab. 9

Exp. 9. Effect of bleeding on utilization of PBG and porphyrin formation by normal bovine hemolysate (\# 3247)

1. Before bleeding (6-26-64). Hb $11.4 \mathrm{gm} / 100 \mathrm{ml}$, $\mathrm{Ht}$. $35.5 \%$, reticulocytes 0 . In the first runs the volumes of packed cells indicated were hemolyzed and diluted as described under Methods. In run 4 the buffer mixture recommended by VAvRA and co-workers (17) was used (see Methods). In runs 1,3 and 4 the blood and hemolysates were refrigerated until incubation. In run 2 no attempt was made to avoid ambient temperature exposure

\begin{tabular}{|c|c|c|c|c|c|c|c|c|c|c|c|c|c|c|}
\hline \multirow[t]{2}{*}{ Run } & \multirow[t]{2}{*}{$\begin{array}{l}\text { Hemo- } \\
\text { lysate } \\
\text { from }\end{array}$} & \multirow[t]{2}{*}{$\begin{array}{l}\text { Hours } \\
\text { incuba- } \\
\text { tion }\end{array}$} & \multirow[t]{2}{*}{$\underset{\substack{m l \\
\text { packed } \\
\text { cells }}}{ }$} & \multirow{2}{*}{\multicolumn{2}{|c|}{${\underset{\text { Before }}{\text { incubation }}}_{\text {After }}^{\mathrm{pH}}$}} & \multirow[t]{2}{*}{$\begin{array}{l}\text { PBG } \\
\text { added } \\
\text { mg }\end{array}$} & \multirow[t]{2}{*}{$\underset{\text { mg }}{\text { remaining }}$} & \multicolumn{4}{|c|}{$\begin{array}{c}\mu \mathrm{g} \text { porphyrins } \\
\text { (pre-incubation values in } \\
\text { parentheses) }\end{array}$} & \multirow[t]{2}{*}{$\begin{array}{l}\text { Total net } \\
\text { increase } \mu g \\
\text { UP I + CPI }\end{array}$} & \multicolumn{2}{|c|}{$C P{ }^{\%}$ III UP* } \\
\hline & & & & & & & & Proto- & incr. & $\mathrm{CP}$ & UP & & & \\
\hline \multirow{2}{*}{$\begin{array}{l}1 \\
2 \\
3 \\
4 \\
5\end{array}$} & \multirow{2}{*}{$\begin{array}{l}\text { t. c. } \\
\text { t. c. } \\
\text { t. c. } \\
\text { t. c. } \\
\text { Control, } \\
\text { no cells }\end{array}$} & $\begin{array}{l}8 \\
8 \\
4 \\
4\end{array}$ & $\begin{array}{l}10 \\
10 \\
15 \\
2.5\end{array}$ & $\begin{array}{l}7.30 \\
7.50 \\
7.35 \\
7.40\end{array}$ & $\begin{array}{l}7.44 \\
7.60 \\
7.48 \\
7.50\end{array}$ & $\begin{array}{l}2.31 \\
2.27 \\
0.63 \\
0.71\end{array}$ & $\begin{array}{l}1.2 \\
1.26 \\
0.27 \\
0.57\end{array}$ & $\begin{array}{r}60(4) \\
40(4) \\
68(6) \\
2(1)\end{array}$ & $\begin{array}{r}56 \\
36 \\
62 \\
1\end{array}$ & $\begin{array}{r}45(0) \\
32(0) \\
31(0) \\
4(0)\end{array}$ & $\begin{array}{r}134(0) \\
157(0) \\
71(0) \\
21(0)\end{array}$ & $\begin{array}{r}84 \\
75 \\
18 \\
8\end{array}$ & $\begin{array}{r}86 \\
100 \\
100 \\
100\end{array}$ & $\begin{array}{l}43 \\
52 \\
74 \\
63\end{array}$ \\
\hline & & 4 & 0 & 7.00 & 5.20 & 0.95 & 0.68 & 0 & 0 & 0 & 2 & - & - & - \\
\hline
\end{tabular}

2. After bleeding (7-10-64), (7.7 liters of blood removed between 6-26 and 7-8). Hb $7.2 \mathrm{gm} / 100 \mathrm{ml}$, Ht. $22 \%$, reticulocytes $0.5 \%$; $3.8 \%$ dark blue supravitally staining cells (with brilliant cresyl blue). L. d. c. and g. d. c. fractions had 1.1 and $0.2 \%$ reticulocytes, 6.3 and $1.8 \%$ dark blue stai-

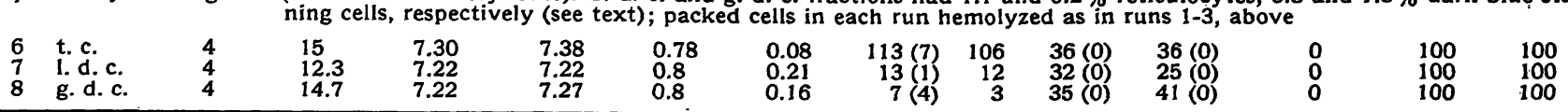
* Differences from $100 \%$ represent type I. In addition, small spots were noted in all runs, both before and after bleeding, indicative of minor
amounts of "pseudouroporphyrin" (7-COOH) 
Tab. 10

Exp. 10. Effect of bleeding on utilization of PBG and porphyrin formation by bovine porphyric hemolysate (\# 3033)

1. Before bleeding (6-29-64). Hb $8.4 \mathrm{gm} / 100 \mathrm{ml}$, Ht. $25 \%$. The blood and hemolysates were kept cold throughout. The same proportions of water to the two $\mathrm{KCl}$ solutions were used as in exp. 9, with a four hour incubation

\begin{tabular}{|c|c|c|c|c|c|c|c|c|c|c|c|c|c|c|}
\hline \multirow[t]{2}{*}{ Run } & \multirow{2}{*}{$\begin{array}{l}\text { Hemo- } \\
\text { lysate } \\
\text { from }\end{array}$} & \multirow{2}{*}{$\begin{array}{l}\text { Reticu- } \\
\text { locytes } \\
\%\end{array}$} & \multirow{2}{*}{$\underset{\substack{m l \\
\text { packed } \\
\text { cells }}}{m^{\prime}}$} & \multirow{2}{*}{\multicolumn{2}{|c|}{$\underset{\text { incubation }}{\text { Before }} \stackrel{\mathrm{pH}}{\text { After }}$}} & \multirow{2}{*}{$\underset{\text { Added }}{\mathrm{mg}}$} & \multirow{2}{*}{$\begin{array}{l}\text { PBG } \\
\text { Remaining }\end{array}$} & \multicolumn{4}{|c|}{$\begin{array}{l}\text { Mg porphyrins } \\
\text { (pre-incubation values in parentheses) }\end{array}$} & \multirow{2}{*}{$\begin{array}{c}\text { Net } \\
\text { increase } \\
\text { UP I + CP I }\end{array}$} & \multicolumn{2}{|c|}{$\%$ III } \\
\hline & & & & & & & & Proto-* & $\begin{array}{l}\text { in- } \\
\text { crease }\end{array}$ & $\mathrm{CP}$ & UP & & $\mathrm{CP}$ & UP \\
\hline $\begin{array}{l}1 \\
2 \\
3\end{array}$ & $\begin{array}{l}\text { t. c. } \\
\text { I. d. c. } \\
\text { g. d. c. }\end{array}$ & $\begin{array}{l}1.5 \\
1.3 \\
0.6\end{array}$ & $\begin{array}{l}15 \\
10 \\
13\end{array}$ & $\begin{array}{l}7.32 \\
7.26 \\
7.30\end{array}$ & $\begin{array}{l}7.45 \\
7.30 \\
7.33\end{array}$ & $\begin{array}{l}0.65 \\
0.74 \\
0.65\end{array}$ & $\begin{array}{l}0.08 \\
0.17 \\
0.18\end{array}$ & $\begin{array}{l}218(113) \\
191(90) \\
167(80)\end{array}$ & $\begin{array}{r}105 \\
101 \\
87\end{array}$ & $\begin{array}{l}32(1.8) \\
29(1.5) \\
30(1.7)\end{array}$ & $\begin{array}{r}91(0.7) \\
90(0.4) \\
117(0.4)\end{array}$ & $\begin{array}{r}83 \\
84 \\
112\end{array}$ & $\begin{array}{l}56 \\
66 \\
52\end{array}$ & $\begin{array}{l}27 \\
20 \\
19\end{array}$ \\
\hline
\end{tabular}

2. After bleeding (7-9-64). 7.9 liters of blond removed since $6-29$. Hb $5.7 \mathrm{gm} / 100 \mathrm{ml}$, Ht. $18 \%$. Hemolysates prepared as above, with a four

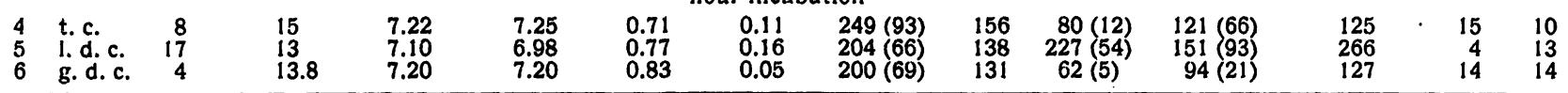

* Meso- in all six runs entirely isomer 9 (III)

Tab. 11

Exp. 11 (9-14-65). Porphyrin formation by normal and porphyric bovine hemolysates in relation to the period of incubation with PBG; $15 \mathrm{ml}$ packed red cells in the hemolysate of each run (see Methods)

\begin{tabular}{|c|c|c|c|c|c|c|c|c|c|}
\hline & \multicolumn{2}{|c|}{ Whole blood } & \multirow[b]{2}{*}{ Hours } & \multirow{2}{*}{$\underset{\mathrm{mg}}{\mathrm{PBG}}$} & \multirow{2}{*}{$\begin{array}{c}\text { Proto- } \\
\text { /gg }\end{array}$} & \multicolumn{3}{|c|}{ Porphyrins and isomers } & \multirow[b]{2}{*}{$\because 1$} \\
\hline & $\mathrm{gm} / 100 \mathrm{ml}$ & $\%$ & & & & $\mu \mathrm{g}$ & $\% 1$ & $\mu \mathrm{g}$ & \\
\hline $\begin{array}{l}\text { Normal without PBG } \\
\text { Incubated (tube 1) } \\
\text { Incubated (tube 2) }\end{array}$ & 13.3 & 0 & $\begin{array}{l}0 \\
4 \\
8\end{array}$ & $\begin{array}{l}0.0 \\
0.0 \\
0.0\end{array}$ & $\begin{array}{r}10.6 \\
9.7 \\
8.2\end{array}$ & $\begin{array}{l}0.45 \\
0.34 \\
0.21\end{array}$ & $\overline{-}$ & $\begin{array}{l}0 \\
0 \\
0\end{array}$ & Z \\
\hline $\begin{array}{l}\text { Normal with PBG (each tube) } \\
\text { Incubated (tube 1) } \\
\text { Incubated (tube 2) } \\
\text { Incubated (tube 3) } \\
\text { Incubated (tube 4) }\end{array}$ & 13.3 & 0 & $\begin{array}{l}0 \\
2 \\
4 \\
6 \\
8\end{array}$ & $\begin{array}{l}0.80 \\
0.47 \\
0.209 \\
0.052 \\
0.0\end{array}$ & $\begin{array}{l}60.0 \\
84.5 \\
89.0 \\
89.0\end{array}$ & $\begin{array}{l}\text { (se } \\
27.0 \\
43.6 \\
50.4 \\
63.0\end{array}$ & $\begin{array}{l}\text { alues } \\
24 \\
19 \\
17 \\
26\end{array}$ & $\begin{array}{r}\text { ve) } \\
48.0 \\
82.3 \\
101.0 \\
87.0\end{array}$ & $\begin{array}{l}\text { lost } \\
\text { lost } \\
42 \\
54\end{array}$ \\
\hline $\begin{array}{l}\text { Porphyric (\# 2955) without PBG } \\
\text { Incubated (tube 1) } \\
\text { Incubated (tube 2) }\end{array}$ & 8.9 & 1.8 & $\begin{array}{l}0 \\
4 \\
8\end{array}$ & $\begin{array}{l}0.017 \\
0.017 \\
0.0\end{array}$ & $\begin{array}{l}119.0 \\
117.0 \\
120.0\end{array}$ & $\begin{array}{r}20.6 \\
10.0 \\
9.0\end{array}$ & $\begin{array}{l}65 \\
75 \\
73\end{array}$ & $\begin{array}{l}1.7 \\
1.6 \\
1.7\end{array}$ & 二 \\
\hline $\begin{array}{l}\text { Porphyric (\# 2955) with PBG (each tube) } \\
\text { Incubated (tube 1) } \\
\text { Incubated (tube 2) } \\
\text { Incubated (tube 3) } \\
\text { Incubated (tube 4) }\end{array}$ & 8.9 & 1.8 & $\begin{array}{l}0 \\
2 \\
4 \\
6 \\
8\end{array}$ & $\begin{array}{l}0.79 \\
0.258 \\
0.026 \\
0.017 \\
0.0\end{array}$ & $\begin{array}{l}192.0 \\
210.0 \\
207.0 \\
211.0\end{array}$ & $\begin{array}{l}53.0 \\
67.0 \\
68.0 \\
72.0\end{array}$ & $\begin{array}{l}\text { alues } \\
19 \\
27 \\
44 \\
52\end{array}$ & $\begin{array}{l}\text { ve) } \\
68.0 \\
77.0 \\
55.0 \\
53.0\end{array}$ & $\begin{array}{l}32 \\
55 \\
55 \\
57\end{array}$ \\
\hline
\end{tabular}

CP and UP in this run was of isomer series III while in run 3 the value for UP is $74 \%$ III. The small porphyrin production in runs 7 and 8 might be related to the relatively low $\mathrm{pH}$. CORNFORD (32) has shown that $\mathrm{pH}$ 8.0 is optimal for isomer III production when using a partially purified isomerase. In this connection the lowest $\mathrm{pH}$ of hemolysate was noted in run 5 , exp. 10 , Table 10 (after bleeding of the porphyric bovine \# 3033). Nevertheless the largest net increase of $\mathrm{CP}+\mathrm{UP} I$ in this exp. is noted in this run. Also a considerable amount of Proto- 9 (III) was formed. We have been unable to correlate the variations in porphyrin formation in Tables 9 and 10 with the $\mathrm{pH}$ variations, nor the latter with variations in amounts of red cells hemolyzed, or PBG added. On the basis of CORNFORD's observation (32) the per cent of type III isomer in runs 4, 5 and 6 , especially run 5 (Tab. 10), may be unduly low in comparison with the values of runs $1-3$ before bleeding. It should be noted again, however, that in run 7 of the preceding exp. 9, with a $\mathrm{pH}^{\circ}$ of but 7.22, only"type III isomer was observed, though the amount was small. This may nevertheless represent partial suppression of the normally plentiful isomerase, in terms of total isomer III produced. Use of the Tris buffer mixture (17) in run 4, Table 9, was associated with essentially the same net increase of total porphyrin as formed in run 3, taking into account the differing volumes of packed cells used. (These differed by a factor of 6.0 while the net increase of total porphyrin differed by a factor of 6.3.)

In exp. 5 (Tab. 5) it is evident that GSH or AMP were evidently inhibitory, in that order. Obviously further experiments are needed to confirm and define this more precisely.

\section{The time factor}

In three of the earlier experiments $(2,4,5)$ in which there was no refrigeration before incubation, the incubation time was 8 hours, thus contributing to a relatively excessive formation of type $I$ isomer since the deaminase would still be available to convert any residual $P B G$ to type $I$ in the absence of isomerase inactivated by heat, both in part before and during the long incubation. As an example, in exp. 5 (Tab. 5) most of the UP and CP at the end of the 8 hour incubation was isomer I, but considerable Proto- was also formed, especially in runs 1 and 2 , and this was shown to be entirely type 9 (III). The time factor was more directly examined in exp. 11 (Tab. 11) where it is noted in the lowest set (porphyric with PBG) that at 2 hours only $32 \%$ UP I was recorded but at 4, 6 and 8 hours, $55-57 \%$. The \% CPI is seen to have increased in even more convincing fashion with time. The data for the normal with PBG in this experiment are incomplete in respect to UP isomer ratio but there is some indication of the same increase of type $I$, however, with the progressive 
Tab. 12

Exp. 12 (4-3-61). Porphyrin formation by hemolysates of total, Iesser and greater density porphyric human red cells, incubated for eight hours with PBG, case 76, M. H. 15

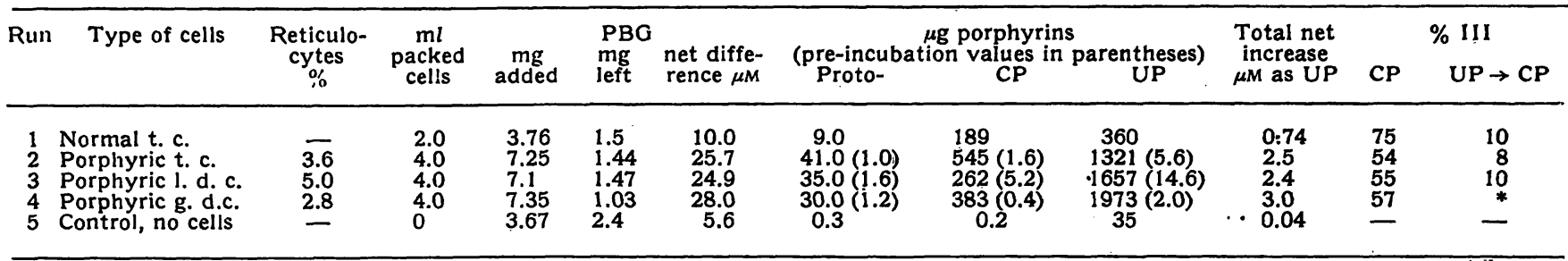

* Lost during decarboxylation

Tab. 13

Exp. 13. Utilization of PBG and porphyrin formation by hemolysates of human porphyric and normal bloods; $10 \mathrm{ml}$ packed cells in each run (see Methods); four hour incubation of hemolysates

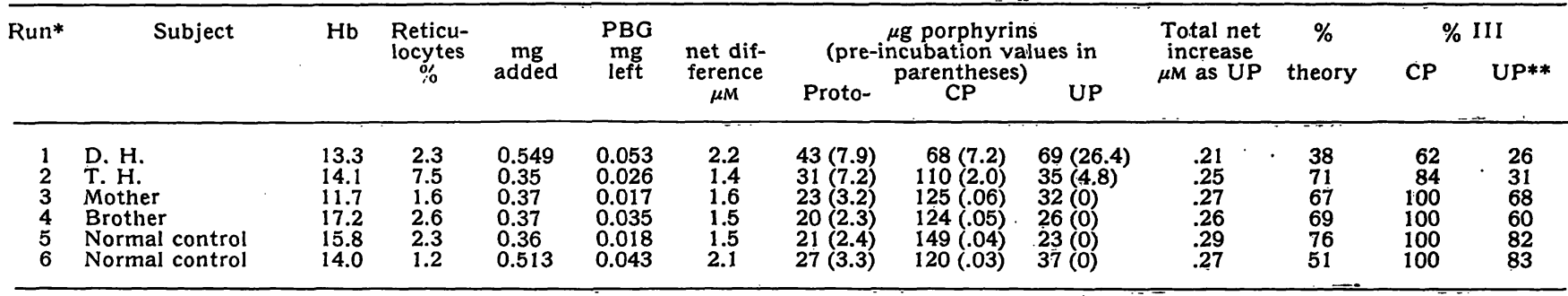

* Runs 2-5 carried out on 11-13-65; runs 1 and 6 on 12-17-68

** Pseudouroporphyrin (7-COOH) spots were observed in runs $3-6$ but not.runs 1 and 2

increase of total CP with time, the variation in proportion of isomers is of doubtful significance.

Coproporphyrin formation

The isomer values for the $\mathrm{CP}$ after incubation are of considerable significance, reflecting to an important degree the UP III which was formed in the hemolysate during the earlier period of incubation, as the decarboxylase converting UP to $\mathrm{CP}^{6}$ ) does not share the extreme temperature sensitivity of the isomerase. Examples are seen in Tables 4, 5 and 8-13, incl. Exp. 12 (Tab. 12) is of special interest as it is the first of two experiments with human porphyric hemolysates, and the only one in which preliminary fractionation of the red cells by centrifugation was carried out. The amounts of $\mathrm{CP}$ are quite large and a majority in each run was type III in contradistinction to the great preponderance of UP I. The data from the normal control in Table 12 are highly significant because of the relatively large amount of CP III ( $75 \%$ of $189 \mu \mathrm{g}$ ) as contrasted with the small amount of UP III $(10 \%$ of $360 \mu \mathrm{g})$. Again, it may be assumed that the UPI is present because of continued deaminase activity after the isomerase has been exhausted, the CP III having been formed early in the course of the 8 hour incubation but not converted to Proto-. The same relatively small conversion of CP III to Proto- is seen in Table 13. This interesting point will be considered in the following.

\section{Reticulocytes and porphyrin formation}

It is seen in Table 12 that despite representing 5\% reticulocytes the 1 . d. c. hemolysate contained less UP

\footnotetext{
6) It may be mentioned again that these designations in the present context include the biologically significant porphyrinogens as well as the porphyrins isolated.
}

and $\mathrm{CP}$ than the hemolysate of the greater density cells albeit these had only $2.8 \%$ reticulocytes. The porphyrin formation was often greater with the $1 . d$. c. hemolysates, as noted in Tables 2, 3, 8 and 10, runs 5 and 6. In Table 13 correlation of reticulocytes and total porphyrin formation by total cell hemolysates is lacking, although the proportion of type I in the porphyric is greater (see below). In all of the bovine porphyric samples the 1. d.c. had significantly greater amounts of native porphyrin. This was likewise true in the human exp. 12 (Tab. 12) but in this instance, unaccountably, the g.d.c. hemolysate formed larger amounts of porphyrin without, however, taking any newly formed heme into account. In run 7 of exp. 6 it is seen that the amounts of native UP and $\mathrm{CP}$ were much greater in the $1 . \mathrm{d}$. c. hemolysate than in the g. d. c. hemolysate of run 8 , yet in the latter there was a greater increase of UP I + CP I than in the former. Again the possibility of a greater heme formation in run 7 cannot be excluded. One must also consider whether the deaminase was limiting because of prior utilization in formation of the large amounts of native porphyrin, although this appears much less likely.

\section{Protoporphyrin 9 (III) formation}

Increased formation of Proto- is evident in many of the hemolysates presently studied. The amounts have generally been larger in the porphyric hemolysates and often in those of the 1. d. c. as contrasted with g. d. c. or t. c. (Tab. 2, 3, 8). Account must be taken, as in Table 3, of the amounts of packed cells and PBG used in different runs. Thus in run $5(1 . \mathrm{d}$. c.) only $2.0 \mathrm{~m} /$ cells and $1.92 \mathrm{mg}$ PBG were used; $115 \mu \mathrm{g}$ of Proto- were observed as contrasted with $139 \mu \mathrm{g}$ in run 4 (t. c.) but in this run $4 \mathrm{ml}$ of cells and $2.9 \mathrm{mg}$ of PBG were used. Another 
example is seen in Table 12 in which the much smaller porphyrin formation in the normal control is related to half as many packed cells and about half as much PBG as in runs 2-4 with porphyric hemolysates. Even taking this into account it is evident that porphyrin formation by the latter was much greater. Collateral data for these experiments including reticulocyte percentages are given in the Tables.

In the single experiment (Tab: 1 ) in which the hemolysates werc obtained by differential osmotic lysis, that of the most fragile formed much more Proto- than that of the most resistant cells.

\section{Discussion}

In considering the significance of the present data due attention must be given to more recent knowledge of porphyrin and heme biosynthesis in erythroid cells, a subject which has been dealt with in an excellent review by GrANiCK (33). In this particular attention is given to mitochondrial as versus soluble enzymes, the former being present in young red cells, the latter also in older cells not containing mitochondria. It is well known that the synthesis of ALA, Proto- and Heme is related to the number of immature cells and corresponding mitochondrial enzyme content of the blood sample used (33-37). The earlier report (8) that the abnormal content of native UP I and CP I of the erythrocytes in erythropoictic (uro-) porphyria is largely in cells which are of lesser density, reticulocyte rich and osmotically more fragile, receives confirmation in the present observations, and has also been confirmed by others $(35,36,37)$.

While in general the 1.d.c. hemolysates formed more porphyrin, a correlation of the net increase with percentage of reticulocytes is often not apparent. In Table 2 it is seen that the l.d.c. had ten times as many reticulocytes as those of greater density but the apparent net increases of porphyrins was scarcely greater in the l. d. c. than in the g. d. c. hemolysate. Also, the difference in percentage of UPI in the two hemolysates is barely significant.

It is evident from the present results that the formation of porphyrin from PBG by hemolysates of either bovine - or human porphyric or normal erythrocytes is affected by various factors, of which temperature is one of the most important. Although the heat sensitivity of the isomerase ("UPG cosynthetase") is well recognized in tcrms of exposure at $55^{\circ}$ for $15-30$ minutes (38), the necessity of protection against even a mild exposure to ambient temperatures for relatively short periods prior to incubation has not been duly recognized. It is also evident that with longer incubation, such as 8 rather than 2-4 hours, the isomerase is more completely inactivated. If PBG is still available the isolated deaminase activity then gives rise to an increasing proportion of UP I in normal as well as pophyric hemolysates. When the blood or hemolysate has not been refrigerated prior to incubation, type UP I may be expected to be the main if not sole representative, although even in such hemolysates significant increase of CP III and Proto- 9 (III) has regularly been noted, indicating that therc was still some isomerase activity, at least in the earlier part of the incubation. An excellent example of the progressively greater deaminase and diminished isomerase activity with time is seen in Table 11, the fourth set of data, i. c., porphyric hemolysates with added PBG. It is seen that as the amount of UP diminishes the proportion of type I stabilizes at about 55\% and at the same time CP I is increasing. Most of the incrcase of Proto- has occurred at the end of 4 hours.

In general the net increases of Proto- were considerably greater in the bovine porphyric than in the corresponding human hemolysates. This may bear fundamental relationship to the characteristically greater erythrocyte Proto- in the bovine than in the human discase. Whenever the Proto- of the present hemolysates was converted to Meso-, this was shown to be the type 9 series III isomer. With the often considerable net increase of CP III, even though together with Proto-, representing less than that of UP and CP I, it is evident that lack of isomerase in this disease is by no means absolute but only relative to a marked increase of deaminase. This is true even in the earlier experiments in which the red cells or hemolysates were not refrigerated prior to incubation with PBG, with consequent diminution of isomerase in relation to deaminase activity (scc Tab. 1, $2,4,5)$.

\section{Uni- vs bimodality of normoblasts?}

In accord with a major objective as discussed at the outset, the data may now be considered in respect to the question of unj- vs bimodality of the erythrocytes in terms of the genetic biochemical abnormality, i. c., the imbalance in the deaminase-isomerasc function favoring excessive formation of UP I.

The data shown in Tables 1, 2, 8, 10 and 12 are of major interest in this regard. In gencral they exhibit greater porphyrin formation by the hemolysates representing grcater proportions of young cells having larger concentrations of native UPI + CPI. The increase of porphyrin on incubation of these hemolysates with PBG is represented to a larger extent by UP I and CP I but there are also very significant increases of CP III and Proto- 9 (III). Interpretation of the latter increases is highly important for the question of uni- or bimodality of the erythrocytes in respect to the genetic abnormality. Of the five experiments in these tables the last three are more significant and will be considered more fully, as in these, in contrast to exps. 1 and 2 , great care was observed in the pre-incubation refrigeration of the blood samples and hemolysates.

In part, at least, the data are compatible with a bimodal distribution. This is especially true of exp. 8 (Tab. 8) in which even with fewer red cells represented in the 1.d.c. hemolysatc, much larger amounts of both UP I + CP I and Proto- 9 (III) were formed. Here one might justifiably assume that among the $7.7 \%$ reti- 
culocytes in this run some representing the genetic abnormality accounted for the type I isomer formation while others, entirely normal, were responsible for the increase of Proto- 9. On the other hand, it might equally well be postulated that all of the reticulocytes are characterized in similar fashion by the isomerasedeaminase imbalance and this is favored by the data in Table 10. Before bleeding the red cells contained but minor increases of native porphyrin with insignificant differences in the three runs. The differences in isomer proportions are of questionable significance. The differences between the data before and after bleeding are highly significant. A considerably greater increase in UPI + CP I is noted in the 1 . d. c. as contrasted with g. d. c. hemolysates but the difference in the increased Proto- 9 (III) formation in the three runs, $4-6$, is insignificant despite the considerable fractionation of reticulocytes. While the UP isomer ratio does not vary significantly in these runs the \% of CP III is distinctly less in the 1 . d. c. run 5 and it is seen that CP I comprises the larger proportion of the total type I isomer formed in this run. This marked increase is roughly correlated with reticulocyte percentage. As described elsewhere (13) the bleeding shown in the table resulted in a sharp increase of fluorescing normoblasts in the bone marrow from 46 to $80 \%$ (13). This finding, considered together with the porphyrin isomer data in Table 10 , is believed to offer strong evidence for a unimodal distribution of normoblasts and erythrocytes in terms of the genetic abnormality. Bovine \#2975, Table 8, had also been bled of 4 liters in the period just prior to the present experiment and although the fluorescing normoblasts were not counted in this instance, it is safe to assume that the same increase to the range of $80-90 \%$ had occurred. The data for the human experiment 12 (Tab. 12) are also of interest in this respect as they fail to show significant differences between 1.d.c. and g. d. c. hemolysates despite considerable difference in reticulocyte percentages in these runs, also the considerably greater native porphyrin content of the $1 . d$.c. run 3 . This is not in accord with a bimodal distribution. Although the UP fraction of run 4 (g. d. c.) was lost before the isomer ratio was determined, it may be assumed from the entirely similar UP isomer ratios of runs 2 and 3 that that of run 4 probably did not differ significantly. Also, the considerable increases of Protoin the porphyric runs (2-4) did not differ significantly. Exps. 1 and 2 may be mentioned briefly in regard to the question of uni- or bimodality, though because there was no refrigeration prior to incubation, the formation of type I isomer was undoubtedly favored. It is fully evident in Table 1 (exp. 1) that hemolysate A, that of the osmotically least resistant cells contained most of the native UP, hence may be assumed to represent a concentration of the genetic-enzymatic error, especially when the values for UP are compared with those for native Proto-. It may be assumed, on the basis of earlier studies (8), that hemolysate A contained a large proportion of the reticulocytes of the starting sample of cells. While this hemolysate formed a great deal more porphyrin including UP, CP and Proto-, the isomer ratios of the UP of hemolysates $A$ and $C$ (runs 1 and 3) are identical, i. e., 70\% I. As mentioned above, these values are probably too high because of some exposure to ambient temperatures, nevertheless, with a bimodal distribution a distinct difference in the UP isomer ratios for runs 1 . and 3 would have been anticipated.

Exp. 2 is of interest because of the marked separation of reticulocytes by fractional centrifugation. The $1 . d$. c. contained most of the native UP and CP, but the net increase of UP I and the UP isomer ratios, differed only slightly between the two hemolysates (runs 1 and 2). The total net increases of porphyrins in these runs were 184 and $165 \mu \mathrm{g}$, respectively. The fact that such small differences were found with hemolysates representing such a marked difference in reticulocytes reveals that the deaminase must have been nearly as adequate with but $10 \%$ as many reticulocytes in the g. d. c. hemolysate (run 2). Since the incubation was for 8 hours, it may be assumed that the available isomerase was exhausted during the first $2-4$ hours, thus permitting the heat stable deaminase to continue its activity in forming UP I. These results do not appear to support a bimodal concept. The large number of reticulocytes indicates a very active erythropoiesis and, as already notéd (13), whenever this has been produced by bleeding, the percentage of fluorescing normoblasts in the bone marrow increases to a degree scarcely compatible with a bimodal distribution.

\section{Additional note on correction of the proof:}

1. Note should have been made in the foregoing of the differences in isomer ratios after incubation in Exp. 13. It is seen that UP I was dominant after incubation of the porphyrin hemolysates, while with those of the mother and brother, quite likely heterozygous, the UP was $60-68 \%$ III, and in the two normal controls $82-83 \%$ III. This suggests that this method may permit detection of heterozygotes. We have not observed differences in native erythrocyte porphyrin concentrations of heterozygote vs normal, such as HEILMEYer and co-workers (40) have described.

2. Since completion of the above studies, LEvin and Coleman (41) have reported observations on the conversion of PBG to porphyrins by a partially purified synthetase (deaminase) from mouse spleen with and without cosynthetase (isomerase) prepared from another fraction of the spleen, or from wheat germ. Using this synthetase with bovine (42) and human (43) porphyric vs normal hemolysates, Levin noted a marked deficiency of cosynthetase in the porphyric cells. However, in this study the possibility was not explored that significant fractions of the uroporphyrinogen III as formed might have been converted in considerable part to $\mathrm{CP}$ and Proto-, as often observed in the present experiments. 


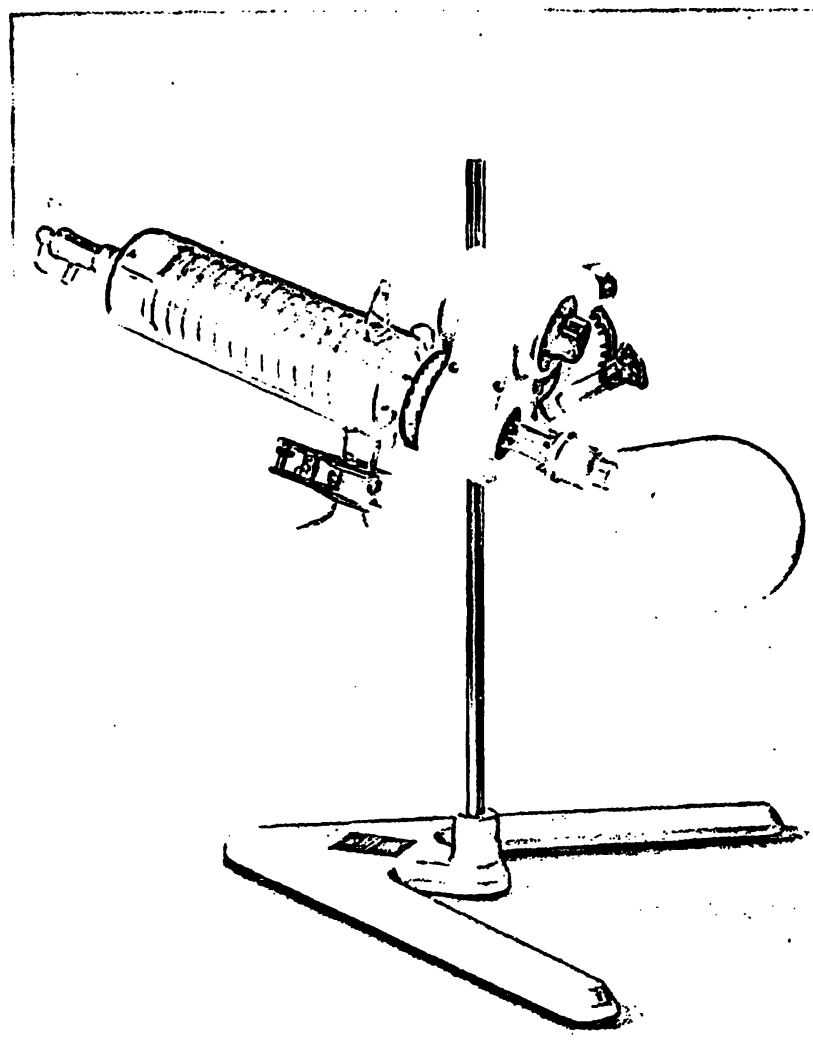

\section{Büchi-Rotavapor R/A}

Der bewährte und erfolgreiche Vakuum-Rotationsverdampfer für schonende und rasche Destillation. Optimale Arbeitsbedingungen durch stufenlose Regulierung der Tourenzahl. Nahezu geräuschloser Betrieb, verstellbare Neigung, Auswechselbarkeit aller Teile.

\section{Alleinvertretung für Deutschland:}

\section{Colora Meßtechnik GmbH}

\section{Lorch/Württ. Postfach 5}

\section{T (07172) 60 41, FS 07-248 886}

Technische Büros (Verkauf und Kundendienst): 1000 Berlin 30, Kurfürstenstraße 84, T 135200 2000 Hamburg 19, Osterstraße 63, T 400606 4000 Düsseldorf, Kronprinzenstr. 62, T 17860 , FS 08-587 253 6000 Frankfurt (Main), Liebigstr. 24, T 72 9613, FS 04-11216 8000 München 2, Dachauer Straße 175, T 5169858

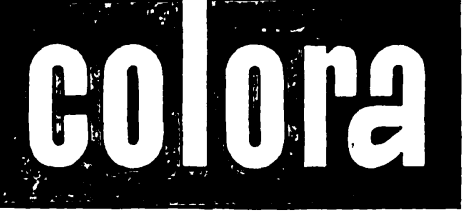

\section{ADVANCED ION-EXCHAÑGE CELLULOSES} specifically designed for the separation and purification of

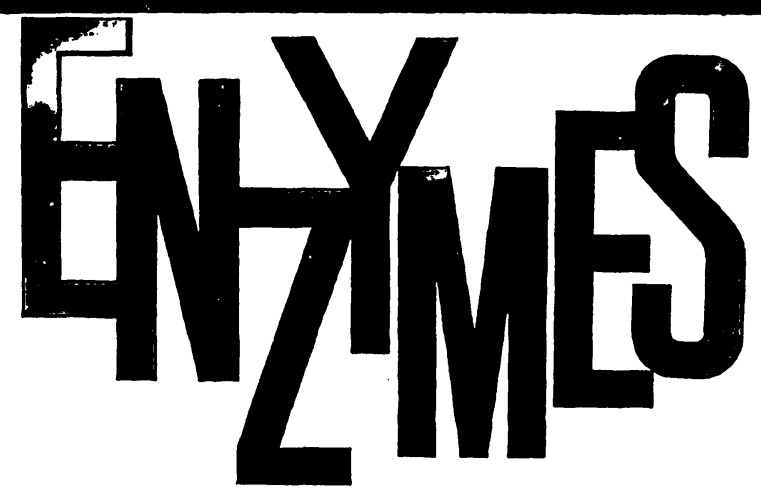

Glycerophosphate Dehydrogenase

Lipoyl Dehydrogenase

Glutamine Synthetase - Aminoacyl Synthetases Creatine Phosphokinase
Trlose Phosphate lsomerase

Glutathlone Reductase - Cytochrome c Reductase

Thioredoxin Reductase - Chicken Liver Dihydrofolic Reductase Nitrate Reductase

Goose Egg Lysozyme : Corn Ribonuclease Lobster Muscle Phosphorylase b C'I Esterase

$$
\begin{aligned}
& \text { Pancreatic Lipase - Proelastase } \\
& \text { Pancreatic Amylase - Trypsinogen } \\
& \text { Chymotrypsinogen } \\
& \text { Renin }
\end{aligned}
$$

Chick Heart Lactic Dehydrogenase Chick Muscle Lactic Dehydrogenase Frog Muscle Lactic Dehydrogenase Horse Liver Alcohol Dehydrogenase

... if you work with enzymes, you'll find Whatman Advanced lon-Exchange Celluloses unlike any other ion-exchange cellulose product you have ever used. Manufactured by a special process, under rigid quality control standards, Whatman AIEC's offer carefully controlled molecular structure, resulting in controlled particle size and shape - which lead to higher capacity ... faster kinetics . . . improved resolution - important advantages when you are working with enzymes.

The enzymes shown are just a few of the many that have been successfully separated on Whatman AlEC's. In addition, equally successful separations have been made with proteins and nucleotides.

Weitere Einzelheiten über die Eigenschaften, Anwendungen und Arbeitsvorschriften finden Sie in den Druckschriften C66B und IE2. Bitte, fordern Sie diese Druckschriften bei uns an.

Alleinvertretung für die Bundesrepublik und West-Berlin:

HOR MUTH - VETTER

6900 Heidelberg 1, Postf.750, Tel. 06221/20045 6908 Wiesloch/Bd., Postf. 1145, Tel. 06222/2147 


\section{References}

1. Watson, C. J., P. T. Lowry, R. Schmid, V. E. Hawkinson and S. Schiwartz, Transact. Ass. Amer. Physicians 54, 345 (1951). 2. Schmid, R., S. Schwartz and C. J. Watson, Arch. Int. Med. Chicago 93, 167 (1954). - 3. SChmid, R., S. Schwartz and D. SundBerg, Blood 10, 416 (1955). - 4. Watson, C. J., W. RuNGe, L. Taddeini, I. Bossenmaier and R. Cardinal, Proc. nat. Acąd. Sci. USA 52, 478 (1964). - 5. Gross, S., M. D. Schoenberd and V. R. Mumaw, Blood 25, 49 (1965). - 6. Ventura, S. and F. OrLandr, Internat. Sympos. on Normal and Path. Metab. of Porphyrins, Saint Vincent 1965. Edizioni Minerva Medica, Panminerva Medica (1965) p. 72. - 7. Rimington, C., Proc. Roy. Soc. Med. 51, 963 (1959). - 8. Watson, C. J., V. Perman, F. A. Spurrell, H. Hoyt and S. Schwartz, Arch. Int. Med. Chicago 103, 436 (1959). - 9. Watson, C. J., S. Gilbertsen, I. BossenMAIER and L. Johnson, In preparation. - 10. BRECHER, G. and F. Stohlman jr., Proc. Soc. exp. Biol. Med. 107, 887 (1961). - 11. Borsook, H., J. B. Lingrel, J. L. Scaro and R. L. Millette, Nature London 196, 347 (1962). - 12. WASs, W. and S. SchWARTZ, Personal communication. - 13. Runge, W. and C. J. Watson, Blood, J. of Hematol., in press. - 14. Wass, W. M. and H. H. Hoyt, Amer. J. Vet. Res. 26, 654 (1965). - 15. Dresel, E. I. B. and J. E. FALK, Biochem. J. 56, 156 (1954). - 16. Dresel, E. I. B. and J. E. FALK, Biochem. J. 63, 80 (1956). - 17. VAVRA, J. D., V. K. MAYer and C. V. Moore, J. Laborat. Clin. Med. S. Louis 63, 736 (1964). - 18. Cookson, G. H. and C. Rimington, Biochem. J. 57, 476 (1954). - 19. Merchante, A., B. Wachenderg and S. Schwartz, Proc. Soc. exp. Biol. Med. 95, 221 (1957). 20. Todd, J. C., A. H. Sanford and Benjamin B. Wells, Clinical Diagnosis by Laboratory Methods. W. B. Saunders, Philadelphia and London (1953) p. 280. - 21. Schalm, O. W., Vetcrinary
Pathology. Lea and Febiger, Philadelphia (1961) p. 160. - 22. Blood and Other Body Fluids. Published by Fed. Amer. Soc. Exp. Biol., Washington, D. C., 1961. (Library of Congress, Catalogue Card No. 61-12371). Analysis and compilation by Philip Altman, edited by Dorothy S. Dittmer. - 23. Aldrich, R. A., V. Hawkinson, M. Grinstein and C. J. Watson, Blood 6, 685 (1951). 24. Schwartz, S. and H. M. WIKORF, J. biol. Chemistry 194, 563 (1952). - 25. Watson, C. J., Arch. Int. Med. Chicago 86, 797 (1950). - 26. Watson, C. J., M. H. Berg, V. E. Hawkinson and I. Bossenmaier, Clin. Chem. New York 6, 71 (1960). - 27. Edmondson, P. R. and S. Schwartz, J. biol. Chemistry 205, 605 (1953). - 28. Erixsen, L., J. Clin. Laborat. Invest. 10, 319 (1958). - 29. Kay, I. T., Proc. nat. Acad. Sci.USA 48, 901 (1962). 30. Aziz, M. A., S. Schwartz and C. J. Watson, J. Laborat. Clin. Med. S. Louis 63, 585 (1964). - 31. Cornford, P. and A. Benson, J. Chromatog. 10, 141 (1963). - 32. Cornford, P., Biochem. J. 91, 64 (1964). - 33. Granick, S. and R. D. Levere, Progr. in Hematol. 4, 1 (1964). - 34. Mauzerall, D., J. Pediatr. S. Louis 64, 5 (1964). - 35. Vavra, J. D. and V. K. Mayer, J. Laborat. Clin. Med. S. Louis 63, 754 (1964). - 36. Vavra, J. D. and S. A. Poff, J. Laborat. Clin. Med. S. Louis 69, 904 (1967). - 37. Smith, J. E. and J. J. Kaneko, Amer. J. Vet. Res. 27, 931 (1966). 38. Booij, H. L. and C. Rimington, Biochem. J. 65, 4p (1957). 39. Grinstein, M., R. A. Aldrich, V. E. Hawkinson, P. T. Lowry and C. J. Watson, Blood 6, 699 (1951). - 40. Heilmeyer, L., R. Clotten, L. Kerp, H. Merker, C. A. Parra and H. P. WeTZEL, Dtsch. med. Wschr. 88,2449 (1963). - 41. Levin, E. Y. and D. L. Coleman, J. biol. Chemistry 242, 4218 (1967). - 42. I.EviN, E. Y., Science Washington 161, 908 (1968). - 43. LeviN, E. Y., personal communication. 